\title{
PRINCÍPIOS NORTEADORES DA SISTEMÁTICA RECURSAL E O PRINCÍPIO DA PRIMAZIA DO MÉRITO NO NOVO CPC
}

THE NORTEADOR PRINCIPLES OF THE RESOURCES SYSTEM AND THE PRINCIPLE OF THE

PRIMAZY OF MERIT IN THE NEW CPC

Marcelo Augusto da SILVEIRA ${ }^{1}$

ISSUE DOI: $10.21207 / 1983.4225 .865$

\section{RESUMO}

Tem a presente resenha o objetivo de elencar os princípios processuais mais estritamente ligados aos "recursos em geral", com ênfase na nova concepção trazida pelo CPC/15 de valorização axiomática da análise do mérito de um processo em detrimento do rigorismo exacerbado muito presente na jurisprudência criada com base no revogado Código de Buzaid, a partir da visão doutrinária do chamado "princípio da primazia ou da preponderência do mérito", aplicável não somente na seara recursal, bem como em todo o ordenamento procedimental processual, para que sempre que possível, todos os atos de um processo sejam tendentes a uma solução de direito material, resultando no efetivo acesso à justiça, na prestação jurisdicional satisfativa e na entrega de um resultado justo.

Palavras-chave: Princípio Recursais, Primazia do Mérito. Novo CPC.

\section{ABSTRACT}

The purpose of this work is to list the procedural principles, most closely linked to "recourse in general", with emphasis on the new conception brought by the CPC/15 of an axiomatic evaluation of the merits analysis of a process, to the detriment of the exacerbated rigor which is very much present in the case-law created on the basis of the abrogated Buzaid Code, from the doctrinal view of the

\footnotetext{
${ }^{1}$ Mestre em Direito Público com dissertação em Processo - Civil - UNIFRAN - 2002. Professor concursado de Direito Processual Civil na Faculdade de Direito de Franca. Coordenador da escola superior da advocacia - ESA - núcleo Franca. Ex- professor de Processo Civil dos cursos de graduação e pós graduação da Universidade de Franca. Autor de livros e artigos jurídicos. Palestrante em cursos de Direito Processual Civil da OAB-SP. Ex- professor de Direito Processual Civil na Universidade de Uberaba - UNIUBE. Advogado militante. http://lattes.cnpq.br/0800198639236104.
} 
"principle of primacy or preponderance of merit" applicable not only to the courts, but also throughout the order procedural law, so that whenever possible, all the acts of a proceeding are directed towards a solution of substantive law, resulting in the effective access to justice, the satisfactory judicial provision and the delivery of a fair result.

Keywords: Appeals Principle, Primate of Merit. New CPC.

\section{INTRODUÇÃO}

Fato notório que o Novo CPC (Lei $\mathrm{n}^{\mathrm{o}}$ 13.105/15 alterada pela de $\mathrm{n}^{\circ}$ 13.256/16), modificou várias regras no campo dos recursos, com destaque para a reformulação do rol das decisões interlocutórias sujeitas ao agravo de instrumento, agora taxativo; o cabimento da apelação contra as decisões interlocutórias não listadas nesse rol; a aceitação do recurso prematuro, aquele protocolado antes do início do prazo; a unificação dos prazos em 15 dias, com a exceção dos embargos de declaração (5 dias); a extinção, em regra, do sistema do duplo juízo de admissibilidade, agora feito somente em segundo grau; a sucumbência recursal; entre outras várias transformações.

Um dos pontos que chama mais a atenção, em especial com relação ao exercício da atividade da advocacia, é a adoção da regra da primazia do mérito, que serve de premissa para todo o Código, evitando-se formalismos exagerados que impedem a análise do mérito das ações e recursos, que se evidencia no próprio texto do código em seu art. $4^{\circ}$ que dita que "as partes têm o direito de obter em prazo razoável a solução integral do mérito, incluída a atividade satisfativa".

Nesse trilho, esse artigo objetivará discorrer sobre a principiologia recursal, com ênfase ao final na impactante alteração legislativa que obriga que o Poder Judiciário sempre leve em conta a possibilidade de acertamento das questões meramente formais, antes de considerar inadmissível o recurso, para que a atividade jurisdicional atinja ao máximo o mérito da causa, com o alcance da definitiva satisfação material do jurisdicionado, como sói acontecer num estado democrático de direito.

Nesse contexto, os princípios são os fundamentos de um sistema. Todo o sistema deve ser analisado com base nos seus respectivos princípios. O que deles fugir não deve subsistir, uma vez que a construção não pode ir contra as suas bases, seus fundamentos, correndo o risco de ruir violentamente. ${ }^{2}$

\footnotetext{
${ }^{2}$ Os Juizados Especiais, a título de exemplo, são informados por uma série de princípios, dentre eles, a celeridade e a informalidade. No intento de promovê-los, o legislador suprimiu de seu procedimento a maioria dos recursos previstos no $\mathrm{CPC} / 73$, resumiu a conciliação, instrução e julgamento a, sempre
} 
Para tanto, imprescindível é o bom entendimento de cada um dos princípios que norteiam a sistemática dos recursos, uma vez que, segundo Carlos Sundfeld, "é o conhecimento dos princípios, e a habilitação para manejá-los, que distingue o jurista do mero conhecedor de textos legais". ${ }^{3}$

\section{PRINCÍPIO DO DUPLO GRAU DE JURISDIÇÃO4}

Uma vez proferida a decisão, a parte pode com ela não se conformar, querendo, portanto, impugná-la.

Consiste na possibilidade de que essa decisão seja revista, o que será feito mediante a interposição de recurso. A rigor, a revisão será feita pela instância superior, no entanto, como se verá adiante há exceções, como no caso dos embargos de declaração.

Além de satisfazer o inconformismo da parte, a revisão atua no sentido de evitar abusos do juiz e corrigir eventuais erros em que este possa incidir, uma vez que ele também é, como não poderia deixar de ser, sujeito à falibilidade humana.

Há argumentos favoráveis e desfavoráveis ao princípio do duplo grau de jurisdição $0^{5}$.

Quanto aos favoráveis, apresentam-se como os de maior peso:

a) Os juízes de segundo grau, em tese, possuem mais experiência, e, assim, maior possibilidade de fazer surgir soluções adequadas aos diversos casos concretos ${ }^{6}$;

que possível, uma só audiência; entre outras disposições, a fim de que ele possa acudir as suas finalidades precípuas, quais sejam, uma justiça célere. No eventual surgimento de regra de direito que obstaculize o bom andamento da marcha processual nos Juizados, deve ela ser afastada pelo juiz, sob pena de inviabilizar o atendimento das finalidades para que foi criado, perdendo, assim, a sua própria ratio essendi (razão de ser).

${ }^{3}$ SUNDFELD, Carlos Ari. Fundamentos de Direito Público. 4.ed. rev., aumentada e atualizada. São Paulo: Malheiros, 2005. p.148.

${ }^{4}$ DOUTRINA CORRELATA - REFLEXÃO: OLIVEIRA, Bruno Silveira de. Duplo grau de jurisdição: princípio constitucional?. São Paulo: Ed. RT, ago. 2008. p. 162.

TEIXEIRA, Guilherme Puchalski. Análise fragmentada do duplo grau, enquanto regra de direito. São Paulo: Ed. RT, abr. 2008. p. 158/350.

${ }^{5}$ Para uma análise aprofundada sobre os argumentos favoráveis e desfavoráveis ao princípio em análise: MARINONI, Luiz Guilherme; ARENHART, Sérgio Cruz. Manual do processo de conhecimento. 5.ed. São Paulo: Revista dos Tribunais, 2006. p. 505-511.

${ }^{6} \mathrm{O}$ Judiciário exerce atividade escalonada, existindo órgãos inferiores e superiores, competindo a esses últimos, em regra, o julgamento dos recursos interpostos pelas partes. É o juízo ad quem reapreciando as decisões do juízo a quo. (Cf. MIRANDA, Gilson Delgado; PIZZOL, Patrícia Miranda. Recursos no processo civil. 6. ed. atual. São Paulo: Atlas, 2009. p. 9 
b) Ao julgar, o juiz de primeiro grau sabe que sua decisão poderá ser revista. Desse modo, agiria com maior zelo e proficiência pela influência psicológica que o duplo grau nele causaria.

Na lição de Pimenta da Veiga: o princípio do duplo grau, assim, é um antídoto contra a tirania judicial. ${ }^{7}$

Na mesma quadra, Flávio Cheim Jorge:

Ao lado disso, imperiosa se torna a necessidade de reexame das decisões para o fim de se atender ao próprio Estado Democrático de Direito, em razão do risco sempre presente, lembrado por ALCIDES DE MENDONÇA LIMA, com base nas lições de Montesquieu, de o juiz se tornar um déspota, abusando do poder a ele conferido. ${ }^{8}$

Já em contraposição a estes, e não menos relevantes elencam-se os argumentos desfavoráveis:

a) O juiz de segundo grau não tem qualquer contato com as partes e com a produção da prova. Logo, embora mais antigo, não se pode dizer que esteja em melhores condições de julgar'. Além do que, ocorre a inutilização do procedimento oral, dado que a decisão que verdadeiramente prevalecerá, a rigor, será aquela do órgão de segundo grau, com base em um procedimento (reduzido a) escrito, e não a do juiz de primeiro grau, que participou do processo e teve contato direto com a produção de provas, o que, inegavelmente, atribui-lhe melhores condições de extrair a verdade dos fatos. Resta, assim, prejudicada a busca da oralidade tão proclamada pelo sistema processual, que tem por grande vantagem a valorização da percepção do julgador ${ }^{10}$;

\footnotetext{
${ }^{7}$ VEIGA, Pimenta in THEODORO Júnior, Humberto. Curso de Direito Processual Civil - Teoria geral do direito processual civil, processo de conhecimento e procedimento comum - vol. III. 46. ed. - Rio de Janeiro: Forense, 2016. P52.

${ }^{8}$ JORGE, Flávio Cheim. Teoria geral dos recursos cíveis. 7. ed. rev., atual. e ampl. - São Paulo: Ed. RT, 2015. p. 261/263.

${ }^{9}$ MARINONI, Luiz Guilherme; ARENHART, Sérgio Cruz; MITIDIERO, Daniel. Novo Código de Processual Civil comentado. 2. ed. rev., atual. e ampl. - São Paulo: Ed. RT, 2016. p 507/508.

${ }^{10} \mathrm{Cf}$. LASPRO, Orestes Nestor de Souza. Duplo grau de jurisdição no direito processual civil. São Paulo: Ed. RT, 1995, p. 133.
} 
b) Uma dupla revisão sempre implica maior gasto de tempo ${ }^{11}$, causando, inevitavelmente, o que a doutrina chama de dano marginal ${ }^{12}$.

Fredie Didie Jr. e Leonardo Carneiro da Cunha pontuam sobre o

tema:

O princípio do duplo grau de jurisdição vem sofrendo críticas de segmento respeitável da doutrina processual. Essa doutrina traz como pontos negativos desse princípio: a dificuldade de acesso à justiça, o desprestígio da primeira instância, a quebra de unidade do poder jurisdicional, a dificuldade na descoberta da verdade e a inutilidade do procedimento oral. ${ }^{13}$

Sob nossa ótica, o moderno processo tem que assegurar aos litigantes a participação ativa na formação do provimento judicial, criticando-o nas hipóteses em que esse não observou as regras formais ou não bem aplicou o direito material ao caso concreto, sob pena de violação ao princípio do contraditório, e a simples possibilidade de revisão por grau hierarquicamente superior diminui o risco de prolação de decisões ilegais e teratológicas, assegurando o que alguns autores denominam de "garantia fundamental de boa justiça" ${ }^{\text {"14 }}$.

\subsection{O DUPLO GRAU É PRINCÍPIO OU GARANTIA CONSTITUCIONAL?}

\footnotetext{
11 "Certamente, o grande desafio do processo civil contemporâneo reside no equacionamento desses dois valores: tempo e segurança. A decisão judicial tem que compor o litígio no menor tempo possível. Mas, deve respeitar também as garantias da defesa (due process of law), sem as quais não haverá decisão segura. Celeridade não pode ser confundida com precipitação. Segurança não pode ser confundida com eternização." (GAJARDONI, Fernando da Fonseca. Reflexos do tempo no direito processual civil - anotações sobre a qualidade temporal do processo civil brasileiro e europeu. São Paulo: Ed. RT, nov. 2007. p. 153/102.).

${ }^{12}$ É o prejuízo que o postulante tem com a demora de obtenção do direito enquanto o outro litigante experimenta um lucro na mesma demora - manutenção do status quo (BIM, Eduardo Fortunato; MAIDAME, Márcio Manoel. Restrições ao poder geral de cautela e derrotabilidade. São Paulo: Ed. RT, ago. 2009. p.175/180.).

${ }^{13}$ DIDIER JR., Fredie; CUNHA, Leonardo José Carneiro da, Curso de direito processual civil: meios de impugnação às decisões judiciais. $5^{\text {a }}$.ed. Salvador: JusPodivm, 2008. p.93.

${ }^{14}$ NERY JÚNIOR, Nelson. Princípios fundamentais cit., p. 37; PERROT, Roger. Le príncipe du double degré de jurisdicion et son évolution en droit privé français. Studi in Onore di Enrico Tullio Liebman. Milano, 1979, v. III, p. 1971 apud THEODORO Júnior, Humberto. Curso de Direito Processual Civil - Teoria geral do direito processual civil, processo de conhecimento e procedimento comum - vol. III. 46. ed. - Rio de Janeiro: Forense, 2016. p. 953.
} 
O duplo grau de jurisdição é previsto na maioria absoluta dos ordenamentos jurídicos de outros países. ${ }^{15}$

Conforme Cândido Dinamarco, "Na ordem constitucional brasileira, não há uma garantia do duplo grau de jurisdição. A Constituição Federal prestigia o duplo grau como princípio, e não como garantia"16-17. Em outras palavras, serão admitidas exceções, isto é, situações em que não será admitido recurso contra o provimento jurisdicional. Se fosse tido por uma garantia, seria ele um direito constitucional, e, consequentemente, o legislador infraconstitucional não poderia criar norma excluindo a possibilidade de revisão, sob pena de inconstitucionalidade, o que, reafirma-se, não é o caso.

Não é recomendável, entretanto, que o legislador retire da parte a possibilidade de revisão da decisão sem um fundamento válido. Para que possa fazê-lo, deve a exclusão ter por base um princípio de hierarquia constitucional que, no caso específico, apresente-se como de maior importância ${ }^{18-19}$. É o que ocorre, por exemplo, quando da necessidade de o Estado promover uma prestação jurisdicional tempestiva, assegurado pela

\footnotetext{
${ }^{15}$ Interessante análise sobre o duplo grau em outros países: OLIVEIRA, Bruno Silveira de. Duplo grau de jurisdição: princípio constitucional?. São Paulo: Ed. RT, ago. 2008. p. 162/362 e ss.

${ }^{16}$ DINAMARCO, Cândido Rangel. A reforma da reforma. São Paulo: Malheiros, 2002, p. 151 apud TEIXEIRA, Guilherme Puchalski. Análise fragmentada do duplo grau, enquanto regra de direito. São Paulo: Ed. RT, abr. 2008. p. 158/350.

${ }^{17}$ [...]porquanto não há, em nosso ordenamento jurídico, a garantia ao duplo grau de jurisdição.[...] (STF, 1'T, RE 357311-SP, rel. Min. Moreira Alves, j. 19.11.2002, DJ 21.02.2003. p.44).

${ }^{18}$ Pensamos, no entanto, que o princípio do duplo grau de jurisdição não deveria ser alvo de mitigação exagerada, a exemplo do que vem ocorrendo através das recentes reformas legislativas bem como. De todo modo, as alterações pelas quais passaram, nos últimos anos, os arts. 496, 1.013, $\$ 3^{\circ}$, e 932, inciso III, todos do CPC/15, realçaram, a nosso ver, o ideal, perceptível em outras reformas legislativas, de se enfatizar a rapidez em detrimento da segurança acerca da correção da decisão judicial. Com isso, evidentemente, diminui-se a intensidade do princípio do duplo grau de jurisdição no ordenamento jurídico brasileiro. (cf. MEDINA, José Miguel Garcia; WAMBIER, Teresa Arruda Alvim. Recursos e ações autônomas de impugnação. São Paulo: Editora Revista dos Tribunais, 2008. p. 50 - (atenção: este autor alterou a citação no tocante ao número dos artigos, ajustando-a ao NCPC, para facilitar o entendimento do leitor).

${ }^{19}$ [...]O duplo grau está no sistema em permanente tensão com o princípio da efetividade do processo..., devendo ser ponderado em situações concretas, obedecendo ao mecanismo da proporcionalidade. Essa ponderação é feita inicialmente pelo legislador, sopesando valores através das normas principiais. Ponderando assim a complexidade da matéria, a importância social da causa, as circunstâncias procedimentais e a duração razoável do processo, pode o legislador, concedendo maior peso à efetividade sem sacrificar (eliminar) os princípios do devido processo legal e ampla defesa, optar por restringir o duplo grau de jurisdição em determinadas causas ou em certas circunstâncias. (MENDONÇA JR., Delosmar. A decisão monocrática do relator e o agravo interno na teoria geral dos recursos. Tese de doutoramento. Pontifícia Universidade Católica de São Paulo, 2006 DIDIER JR., Fredie; CUNHA, Leonardo José Carneiro da, Curso de direito processual civil: meios de impugnação às decisões judiciais. $5^{\mathrm{a}}$.ed. Salvador: JusPodivm, 2008. p. 28.).
} 
Constituição em seu artigo $5^{\circ}$, inciso LXXVIII ${ }^{20}$. Se, no caso específico, a possibilidade de recurso torne a prestação jurisdicional inútil, pela urgência que demanda, ou pela natureza da $\operatorname{lide}^{21}$, ou ainda, em razão do valor da causa $^{22}$, plausível que se exclua a via recursal. Vê-se que, in casu, a tempestividade/celeridade falou mais alto que a segurança trazida pela revisão do decisorium.

Para todos os efeitos, embora inexista texto expresso na Lei Maior, a doutrina admite que o duplo grau de jurisdição encontra-se implícito nesta ${ }^{23}$, por meio da interpretação gramatical do inciso LV do art. $5^{\circ}$, nos seguintes termos: "Aos litigantes, em processo judicial ou administrativo, e aos acusados em geral, são assegurados o contraditório e ampla defesa, com os meios e recursos a ela inerentes".

Ademais, ainda no bojo constitucional, verifica-se que a previsão relativa aos Órgãos componentes do Poder Judiciário, insculpida no artigo 92, de per si, indica sem sofisma que, se existem instâncias hierarquicamente organizadas, servem elas para que as partes possam obter o reexame da matéria por outros julgadores ${ }^{24}$.

Ainda que consideremos a dualidade de graus como princípio constitucional, vale a ressalva feita por Humberto Theodoro $\mathrm{Jr}^{25}{ }^{2}$ :

No entanto, a própria Constituição prevê processos de competência originária de tribunais, sem superpor-lhes uma instância

\footnotetext{
${ }^{20}$ Art. $5^{\circ}$, inc. LXXVIII/CF - a todos, no âmbito judicial e administrativo, são assegurados a razoável duração do processo e os meios que garantam a celeridade de sua tramitação.

${ }^{21}$ Cabe, a título de ilustração, mencionar a falta de previsão de agravo "nas causas de menor complexidade" dos Juizados Especiais Cíveis Estaduais (Lei 9.099/95), matéria que é tratada apenas por Enunciado do FONAJE [Enunciado 15 - Nos Juizados Especiais não é cabível o recurso de agravo, exceto nas hipóteses dos artigos 544 e 557 do CPC (correspondente aos arts. 1.042 e 932/NCPC, respectivamente)], bem como a sua exclusão a não ser em casos urgentes na Lei dos Juizados Especiais Federais, artigo $5^{\circ}$ : Exceto nos casos do art. $4^{\circ}$, somente será admitido recurso de sentença definitiva.

${ }^{22}$ Veja-se a limitação recursal dada pelo Art. 34 da Lei 6.830/80 (Execuções fiscais) "Das sentenças de primeira instância proferidas em execuções de valor igual ou inferior a 50 (cinqüenta) Obrigações Reajustáveis do Tesouro Nacional - ORTN, só se admitirão embargos infringentes e de declaração.".

${ }^{23}$ Cf. THEODORO JÚNIOR, Humberto. Curso de direito processual civil. v.1. Rio de Janeiro: Forense, 2009. p. 562. Ver também: MONTENEGRO FILHO, Mizael. Curso de Direito Processual Civil: teoria geral dos recursos, recursos em espécie, e processo de execução. v. 2. $4^{\text {a }}$.ed. São Paulo: Atlas, 2007. p. 19.

${ }^{24}$ Art. 92/CF - São órgãos do Poder Judiciário: I - o Supremo Tribunal Federal; I-A o Conselho Nacional de Justiça; II - o Superior Tribunal de Justiça; III - os Tribunais Regionais Federais e Juízes Federais; IV - os Tribunais e Juízes do Trabalho; V - os Tribunais e Juízes Eleitorais; VI - os Tribunais e Juízes Militares; VII - os Tribunais e Juízes dos Estados e do Distrito Federal e Territórios.

${ }^{25}$ THEODORO Júnior, Humberto. Curso de Direito Processual Civil - Teoria geral do direito processual civil, processo de conhecimento e procedimento comum - vol. III. 46. ed. - Rio de Janeiro: Forense, 2016. p.952-953.
} 
revisora. E, mais ainda, prevê juizados especiais em que o recurso, acaso interposto, não sobe a um tribunal superior, mas é examinado por grupo de juízes de primeiro grau, integrados ao próprio juizado. Isso quer dizer que o princípio do duplo grau está naturalmente implantado entre nós, mas não em termos absolutos, cabendo ao legislador ordinário dar-lhe os contornos práticos que se mostrarem convenientes.

Em decorrência do exposto, apesar de não constar expressamente da CF/1988, há princípios que são constitucionais de forma implícita como é o caso. Pensamos que a sua observância é de rigor, apenas com a ressalva que as exceções à dualidade de graus poderão ser estabelecidas com parcimônia pelo legislador, com a restrição ou até mesmo a eliminação de recursos, em alguns casos específicos, até mesmo por respeito a outros princípios que se contrapõem ao duplo grau (celeridade, informalidade, simplicidade, economia processual), sem que isso queira dizer, que, qualquer supressão da via recursal configuraria afronta à ordem constitucional, com primazia inexorável dos princípios da ampla defesa e do contraditório.

São exemplos dessa restrição ou eliminação de recursos o que ocorre no microssistema dos Juizados Especiais Cíveis, no qual, algumas decisões são irrecorríveis, em especial a falta de previsão de agravo de instrumento contra decisões interlocutórias na Lei 9.099/95. Outra situação que demonstra a atuação do legislador sem levar em conta o duplo grau se verifica no art. 34 da Lei. 6.830/8026 - Lei de Execuções fiscais, no qual há proibição da utilização da apelação contra sentença de condenação inferior a 50 ORTN, e ainda, a imposição de que o recurso - chamado de embargos infringentes - seja julgado pelo mesmo juiz que preferiu a sentença.

Outra possibilidade é estampada no art. $1.013, \S 3^{\circ 27}$ do NCPC, de que o tribunal julgue temas não tratados pelo juiz de primeiro grau em

\footnotetext{
${ }^{26}$ Lei 6.830/80, art. 34 - Das sentenças de primeira instância proferidas em execuções de valor igual ou inferior a 50 (cinquenta) Obrigações Reajustáveis do Tesouro Nacional - ORTN, só se admitirão embargos infringentes e de declaração. $\S 1^{\circ}$ - Para os efeitos deste artigo considerar-se-á o valor da dívida monetariamente atualizado e acrescido de multa e juros de mora e de mais encargos legais, na data da distribuição. $\S 2^{\circ}$ - Os embargos infringentes, instruídos, ou não, com documentos novos, serão deduzidos, no prazo de 10 (dez) dias perante o mesmo Juízo, em petição fundamentada. § $3^{\circ}$ - Ouvido o embargado, no prazo de 10 (dez) dias, serão os autos conclusos ao Juiz, que, dentro de 20 (vinte) dias, os rejeitará ou reformará a sentença.

${ }^{27}$ Art. 1.013, $\S 3^{\circ} \mathrm{CPC} / 15$ - Se o processo estiver em condições de imediato julgamento, o tribunal deve decidir desde logo o mérito quando: I - reformar sentença fundada no art. 485;

II - decretar a nulidade da sentença por não ser ela congruente com os limites do pedido ou da causa de pedir; III - constatar a omissão no exame de um dos pedidos, hipótese em que poderá julgá-lo; IV -
} 
sua sentença, na hipótese de afastamento da tese adotada por este último, o que evidencia que algumas situações não são alcançadas pelo princípio do duplo grau, porque na prática, serão julgadas pela primeira vez no tribunal.

\section{$3 \quad$ PRINCÍPIO DA COLEGIALIDADE}

O princípio enuncia que os recursos devem ser julgados por órgão colegiado dos tribunais. O órgão colegiado é o juiz natural dos recursos ${ }^{28}$.

No entanto, em nome da maior celeridade - relembrando o art. $5^{\circ}$, inc. LXXVIII/CF ${ }^{29}$ - e racionalização no processamento dos recursos ${ }^{30}$, o princípio vem sendo mitigado. A tendência é a de que, cada vez mais, sejam atribuídos poderes ao relator para decidir monocraticamente, em substituição aos Tribunais, o que se mostra lógico e coerente com as modernas finalidades da sistemática recursal brasileira.

É fato notório que os Tribunais se encontram abarrotados de processos, processos esses que, no mais das vezes, demandam a apreciação de matéria idêntica. Fazer com que seus órgãos colegiados tenham de se pronunciar sobre a mesma matéria reiteradas vezes é nada mais do que perda de tempo e má utilização dos recursos humanos dos Tribunais. Além do que, quanto maior for o número de processos em um juízo, maior a tendência de decisões de baixa qualidade, o que indubitavelmente deve ser evitado.

Nesse intento, o Novo CPC confere, terminantemente, maiores poderes ao relator para que, ao receber o recurso, monocraticamente, possa não só admiti-lo ou a ele negar seguimento (juízo de admissibilidade - inc. III do art. 932), mas também negar provimento ao recurso (juízo de mérito), quando a decisão atacada tenha fulcro em: a) súmula do STF ou STJ ou do

decretar a nulidade de sentença por falta de fundamentação. $\S 4^{\circ}$ Quando reformar sentença que reconheça a decadência ou a prescrição, o tribunal, se possível, julgará o mérito, examinando as demais questões, sem determinar o retorno do processo ao juízo de primeiro grau. $\S 5^{\circ} \mathrm{O}$ capítulo da sentença que confirma, concede ou revoga a tutela provisória é impugnável na apelação.

${ }^{28}$ MEDINA, José Miguel Garcia; WAMBIER, Teresa Arruda Alvim. Recursos e ações autônomas de impugnação. São Paulo: Editora Revista dos Tribunais, 2008, p. 56.

${ }^{29}$ Art. $5^{\circ}$, inciso LXXVIII CF - A todos, no âmbito judicial e administrativo, são assegurados a razoável duração do processo e os meios que garantam a celeridade de sua tramitação. (Incluído pela Emenda Constitucional $\mathrm{n}^{\circ} 45$, de 2004).

${ }^{30}$ BUENO, Cassio Scarpinella. Curso sistematizado de direito processual civil.: recursos, processos e incidentes nos tribunais, sucedâneos recursais: técnicas de controle das decisões jurisdicionais. São Paulo: Saraiva, 2008. p. 19. v. 5. 
próprio Tribunal, b) em acórdão proferido pelo STF ou STJ em julgamento recursos repetitivos e c) em entendimento firmado em incidente de resolução de demandas repetitivas ou de assunção de competência (inciso IV do art. 932/NCPC - nestes casos com razão a decisão, o recurso é que contraria precedentes) ou ainda, nestas mesmas três hipóteses, dar provimento a recurso, caso a decisão tenha contrariado esses precedentes (inc. V do art. 932 - nestes casos com razão o recurso - a decisão é que é contrária aos precedentes) matéria que será detalhada adiante.

A partir destas atribuições concedidas ao relator (poder-dever) para negar e dar provimento singularmente a recursos, a atuação dos tribunais em órgãos colegiados, em sua competência recursal, foi eficientemente diminuída.

Frisa-se que a tendência de conferir maiores poderes ao relator está em consonância na incessante busca de uma maior celeridade e efetividade da prestação jurisdicional, sem exclusão da segurança jurídica, do contraditório e da ampla defesa. De fato, poderá a parte que não se contentar com a decisão monocrática do relator, se valer de uma modalidade recursal, como será vista adiante, denominada de agravo interno, colocando a questão à apreciação do órgão colegiado.

Desse modo, é barrada grande parte dos recursos que nele chegam e os órgãos colegiados disporão de maior tempo para a apreciação dos casos em que ainda não há posicionamento formado. É a adoção de uma das maiores inovações do novo CPC, a cultura da observância dos precedentes.

Poder-se-ia alegar, in casu, que a parte sofrerá restrição em seu direito, posto que sua decisão não será analisada pelo colegiado, o que resta infundado. A decisão do relator estará fundada no posicionamento que já adotam os colegiados daquele tribunal e de tribunais superiores, e, se ainda assim a parte se sentir inconformada, em atenção ao princípio em comento, poderá ela recorrer da decisão do relator mediante agravo interno para o colegiado, conforme 1.021/NCPC.

Sobre este tópico, preleciona Luiz Guilherme Marinoni, Sérgio Cruz Arenhart e Daniel Mitidiero que: 
monocrática representa simples delegação de poder do colegiado ao relator. $^{31}$

\subsection{PRINCÍPIO DA RESERVA DE PLENÁRIO}

A reserva de plenário é decorrência do princípio da colegialidade.

Conforme dispõe o art. 97 da Constituição Federal, "somente pelo voto da maioria absoluta de seus membros ou dos membros do respectivo órgão especial poderão os tribunais declarar a inconstitucionalidade de lei ou ato normativo do Poder Público".

Declarar a inconstitucionalidade de uma lei, ainda que por via difusa, afastando-a do caso concreto, é algo grave, que exige experiência e reflexão. A Constituição, ao determinar que, em âmbito recursal, isso só possa ser feito pelo Pleno - conjunto dos órgãos colegiados de um Tribunal (ou Órgão Especial - dependendo da nomenclatura utilizada no Regimento Interno do Tribunal), não fez, portanto, exigência vã.

O dispositivo acima é claro ao enunciar a rigorosa exigência que faz a Constituição em relação à observância do princípio da colegialidade quando determina que isso seja feito não apenas pelo órgão colegiado, mas pelo conjunto destes. Quanto ao Órgão Especial, a rigor, dispõem os Regimentos que o preveem, que é formado pelo conjunto dos juízes mais antigos do Tribunal, o que pressupõe maior experiência no julgar, atendendo, assim, às finalidades do referido dispositivo constitucional.

Todavia, há uma exceção: O art. 949, parágrafo único/NCPC declara que "os órgãos fracionários dos tribunais não submeterão ao plenário ou ao órgão especial a arguição de inconstitucionalidade quando já houver pronunciamento destes ou do plenário do Supremo Tribunal Federal sobre a questão". É medida que se coaduna com o princípio da economia e eficiência processuais $^{32}$ e que não deve ser tida por inconstitucional, uma vez que simplesmente será reproduzido posicionamento já proferido pelo órgão especial ou do pleno daquele mesmo tribunal ou pelo plenário do STF sobre a questão. A penada será feita pela caneta do órgão fracionário, no entanto, será mera transcrição do

\footnotetext{
${ }^{31}$ MARINONI, Luiz Guilherme; ARENHART, Sérgio Cruz; MITIDIERO, Daniel. Novo Código de Processual Civil comentado. 2. ed. rev., atual. e ampl. - São Paulo: Ed. RT, 2016. p. 878-879.

${ }^{32}$ BUENO, Cassio Scarpinella. Curso sistematizado de direito processual civil.: recursos, processos e incidentes nos tribunais, sucedâneos recursais: técnicas de controle das decisões jurisdicionais. São Paulo: Saraiva, 2008. p. 20. v. 5.
} 
que já pensa o órgão máximo do próprio tribunal ou por posição firmada pelo Plenário da Suprema Corte. Daí a sua constitucionalidade.

Em epítome, conforme Fernanda Pantoja, "atribui-se, desse modo, eficácia vinculativa às decisões anteriores do pleno (do próprio tribunal ou do STF) em que já houver sido examinada, incidenter tantum, a questão constitucional" "33 (grifo nosso), preservando-se as disposições já firmadas e consolidadas anteriormente sobre os mesmos temas, com prestígio aos precedentes vinculativos estampados no novo CPC.

\section{4

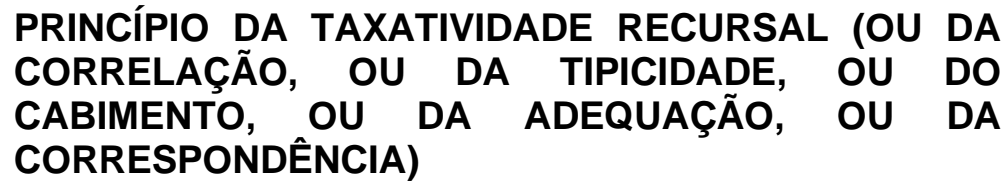

O princípio enuncia que os recursos somente podem ser criados por lei federal, conforme competência a esta atribuída pelo art. $22, \mathrm{I} / \mathrm{CF}^{34}$, não se admitindo que qualquer outro ente federativo edite lei inovando o sistema recursal pátrio. Decorre, como se vê, do princípio da legalidade.

Por conseguinte, não há como admitir a criação de recursos pelos tribunais brasileiros, nem pelas partes - ainda que de comum acordo - nem pela doutrina, razão pela qual se deve reputar inconstitucional a previsão de qualquer recurso por leis estaduais ou municipais, ou ainda, por regimento interno de tribunal.

Indaga-se a respeito do art. 24, XI/CF, que diz competir à União, aos Estados e ao Distrito Federal legislar, concorrentemente, sobre "procedimentos em matéria processual". Não estaria o dispositivo permitindo também aos Estados a criação de recursos?

Não. A norma não conflita com o art. 22, I/CF, que atribui à União competência privativa para tanto.

No que atine aos recursos, matéria procedimental apta a ser criada por lei estadual é aquela que diz respeito à forma do exercício do

\footnotetext{
${ }^{33}$ PANTOJA, Fernanda Medina in ALVIM, Teresa Arruda et al, coordenadores. Breves comentários ao Novo Código de Processo Civil. São Paulo: Ed. RT, 2015. p. 2.118.

${ }^{34}$ Art. 22/CF - Compete privativamente à União legislar sobre: I - direito civil, comercial, penal, processual, eleitoral, agrário, marítimo, aeronáutico, espacial e do trabalho. (grifo nosso)
} 
direito de recorrer ${ }^{35}$, e não aquela que cria o direito de recorrer - recurso em um caso específico ${ }^{36}$. Nem a inclusão do novo art. 190 do $\mathrm{CPC}^{37}$ altera esse quadro, pois a possibilidade de alteração ali prevista se relaciona com a possibilidade das partes alterarem as regras procedimentais a serem adotadas, mas de em nenhuma hipótese à alteração de regras processuais e tampouco acena para a criação de novos recursos.

Sob o ponto de vista prático, os tribunais têm criado os agravos regimentais, mas que não ofendem ao que disposto na Constituição, uma vez que tratam de mera repetição em seus regimentos de recurso já previsto no CPC contra decisões monocráticas de relator, o "agravo interno", disciplinado no art. $1.021 .^{38}$

Os recursos da sistemática recursal cível não são somente aqueles constantes do art. 994/NCPC ${ }^{39}$, mas sim também todo e qualquer recurso criado por legislação extravagante federal. São exemplos: o recurso inominado dos Juizados Especiais (art. 41 da Lei 9.099/95) e os embargos infringentes da Lei 6.830/80 (Lei de Execução Fiscal), que não se

${ }^{35}$ BUENO, Cassio Scarpinella. Curso sistematizado de direito processual civil.: recursos, processos e incidentes nos tribunais, sucedâneos recursais: técnicas de controle das decisões jurisdicionais. São Paulo: Saraiva, 2008. p. 20. v. 5.

${ }^{36}$ Admitindo a dispensa de revisor em recurso de apelação, por regimento interno de tribunal (alteração do procedimento): STJ, $5^{\text {a }}$ T., AgRg no REsp 845.237/DF, rel. Min. Felix Fischer, j. 27.02.2007, DJ 26.03. 2007, p. 279. / Impedindo ao Regimento Interno se sobrepor à previsão legal de recurso (direito de recorrer): STJ, Corte Especial, AgRg na SLS 116/PA, j. 20.03.2006, DJ 03.04.2006, p.192. (grifo nosso)

${ }^{37}$ Art. 190. CPC/15 - Versando o processo sobre direitos que admitam autocomposição, é lícito às partes plenamente capazes estipular mudanças no procedimento para ajustá-lo às especificidades da causa e convencionar sobre os seus ônus, poderes, faculdades e deveres processuais, antes ou durante o processo. Parágrafo único. De ofício ou a requerimento, o juiz controlará a validade das convenções previstas neste artigo, recusando-lhes aplicação somente nos casos de nulidade ou de inserção abusiva em contrato de adesão ou em que alguma parte se encontre em manifesta situação de vulnerabilidade.

${ }^{38}$ Art. 1.021. CPC/15 - Contra decisão proferida pelo relator caberá agravo interno para o respectivo órgão colegiado, observadas, quanto ao processamento, às regras do regimento interno do tribunal. § 1 - Na petição de agravo interno, o recorrente impugnará especificadamente os fundamentos da decisão agravada. $\S 2$ o $\mathrm{O}$ agravo será dirigido ao relator, que intimará o agravado para manifestar-se sobre o recurso no prazo de 15 (quinze) dias, ao final do qual, não havendo retratação, o relator levá-lo-á a julgamento pelo órgão colegiado, com inclusão em pauta. § $3^{\circ}$ É vedado ao relator limitar-se à reprodução dos fundamentos da decisão agravada para julgar improcedente o agravo interno. § 4o Quando o agravo interno for declarado manifestamente inadmissível ou improcedente em votação unânime, o órgão colegiado, em decisão fundamentada, condenará o agravante a pagar ao agravado multa fixada entre um e cinco por cento do valor atualizado da causa. § $5^{\circ} \mathrm{A}$ interposição de qualquer outro recurso está condicionada ao depósito prévio do valor da multa prevista no § 4ํo à exceção da Fazenda Pública e do beneficiário de gratuidade da justiça, que farão o pagamento ao final.

${ }^{39}$ Art. 994 CPC/15 - São cabíveis os seguintes recursos: I - apelação; II - agravo de instrumento; IIIagravo interno; IV - embargos de declaração; V - recurso ordinário; VI - recurso especial; VII recurso extraordinário; VIII - agravo em recurso especial e extraordinário; IX - embargos de divergência. 
confundem com os extinto embargos infringentes existentes sob a égide do $\mathrm{CPC} / 73$, dentre outros.

Para cada decisão, a lei prevê um recurso correspondente, correlato. $\mathrm{O}$ recurso formalmente adequado para o caso será aquele que a lei, segundo requisitos já nela fixados (formalmente), considerar como o apto para atacar a decisão (adequado).

Por outro enfoque, é de se afirmar que a parte recorrente terá que analisar se há recurso previsto em lei, no CPC ou em legislação extravagante, contra a decisão que ela pretende promover a revisão no tribunal, pois somente se a decisão se amoldar ao recurso correspondência - é que tal princípio restaria observado. Contra sentença há previsão de apelação (art. $1.009 \mathrm{NCPC}^{40}$ ); contra decisões interlocutórias taxativamente previstas no art. 1.015 do $\mathrm{NCPC}^{41}$ a lei faz menção expressa ao recurso de agravo de instrumento; já contra sentenças proferidas no âmbito dos Juizados Especiais Cíveis, caberia recurso inominado (art. 41 da Lei 9.099/95), entre outros tantos exemplos.

A falta da observância destas regras taxativas (numerus clausus) para o recurso torna-o inadmissível.

\section{PRINCÍPIO DA UNIRRECORRIBILIDADE (OU DA UNICIDADE, OU DA SINGULARIDADE)}

Enquanto a taxatividade impõe que, para a decisão atacada deverá ter recurso previsto expressamente em lei federal, a unirrecorribilidade exige que esse recurso seja único. Vale dizer que, o princípio da unicidade declara que para cada decisão será cabível a interposição de um só recurso, ou seja, não poderá a parte se valer de dois

\footnotetext{
${ }^{40}$ Art. 1.009. CPC/15 - Da sentença cabe apelação.

${ }^{41}$ Art. 1.015. CPC/15 - Cabe agravo de instrumento contra as decisões interlocutórias que versarem sobre: I - tutelas provisórias; II - mérito do processo; III - rejeição da alegação de convenção de arbitragem; IV - incidente de desconsideração da personalidade jurídica; V - rejeição do pedido de gratuidade da justiça ou acolhimento do pedido de sua revogação; VI - exibição ou posse de documento ou coisa; VII - exclusão de litisconsorte; VIII - rejeição do pedido de limitação do litisconsórcio; IX admissão ou inadmissão de intervenção de terceiros;

X - concessão, modificação ou revogação do efeito suspensivo aos embargos à execução; XI redistribuição do ônus da prova nos termos do art. 373, § $1^{\circ}$; XII - (VETADO); XIII - outros casos expressamente referidos em lei. Parágrafo único. Também caberá agravo de instrumento contra decisões interlocutórias proferidas na fase de liquidação de sentença ou de cumprimento de sentença, no processo de execução e no processo de inventário.
} 
recursos simultaneamente para atacar o mesmo julgado ${ }^{42}$. Esse raciocínio parte do provérbio latino electa una via, non datur recursus al alterum (escolhido um caminho, não é dado recurso para outro).

No entanto, há uma exceção aparente a esse princípio, cunhada no art. 1.029 do $\mathrm{NCPC}^{43}$, que prevê a simultânea propositura do recurso especial e do extraordinário, para o Superior Tribunal de Justiça (questão federal) e para o Supremo Tribunal Federal (questão inconstitucional), tudo com referência a um só acórdão. Todavia, as questões atacadas em cada um dos recursos, serão distintas, não ocorrendo, portanto, dupla impugnação sobre a mesma matéria. ${ }^{44}$

Como visto, a possibilidade de apresentação de dois recursos contra o mesmo acórdão ocorre na esfera dos "recursos extraordinários" lato sensu (recurso extraordinário e recurso especial). Assim, quando uma decisão os desafiar, a interposição de ambos há de ser feita concomitantemente. Não obstante, há uma ratio juris para tanto: a decisão, in casu, terá por base fundamentos distintos ${ }^{45}$, cada qual desafiando um deles, quais sejam, violação a um dispositivo constitucional - no caso do Recurso Extraordinário - e a um dispositivo infraconstitucional - no caso do Recurso Especial. Além do mais, a própria Lei determina que o prazo para a interposição de ambos é comum, de 15 dias úteis, sendo que, dentro desse prazo, se a parte só ajuizar um deles, não poderá se valer do outro posteriormente, posto que ter-se-á operado a preclusão consumativa.

O NCPC pacificou uma questão que perdurou polêmica por muito tempo na doutrina e jurisprudência, sobre a possibilidade de recursos diferentes para cada capítulo da decisão, como nas hipóteses de que, julgado o pedido de concessão dos benefícios da assistência judiciária gratuita, ou ainda, o deferimento de antecipação de tutela na sentença, seria cabível agravo de instrumento quanto a esses capítulos, por terem natureza

\footnotetext{
${ }^{42}$ Consoante o princípio da unirrecorribilidade, é vedada a utilização de duas vias recursais para a impugnação de um mesmo ato judicial. Assim, a interposição simultânea de dois agravos regimentais pela mesma parte, ainda que por procuradores diversos, incide na preclusão consumativa em relação ao segundo recurso. (STJ, $5^{\text {a }}$ T., AgRg no REsp 927.113/SP, rel. Min. Jorge Mussi, j. 24.04.2008, DJ 19.05.2008, p.1).

${ }^{43}$ Art. 1.029. CPC/15 - O recurso extraordinário e o recurso especial, nos casos previstos na Constituição Federal, serão interpostos perante o presidente ou o vice-presidente do tribunal recorrido, em petições distintas que conterão: (...).

${ }^{44}$ THEODORO JÚNIOR, Humberto. Curso de Direito Processual Civil - Teoria geral do direito processual civil, processo de conhecimento e procedimento comum - vol. III. 46. ed. - Rio de Janeiro: Forense, 2016. p. 957.

${ }^{45}$ FUX, Luiz. Curso de direito processual civil. Rio de Janeiro: Forense, 2001. p. 791.
} 
de decisões interlocutórias, e quanto ao mais da sentença, seria interponível a apelação.

O STJ $^{46}$ já vinha pacificando o entendimento quanto ao cabimento exclusivo da apelação. De acordo com a teoria finalística empregada para classificação dos atos judiciais no NCPC, a decisão não é mais analisada sob o prisma do caráter de incidentalidade ou mérito do pedido, mas quanto ao momento (final da fase cognitiva) e conteúdo (com ou sem julgamento do mérito), motivo pelo qual se a decisão encerra a fase de conhecimento, ela se caracteriza como sentença, objetável apenas por um único recurso: apelação. Já se a decisão não teve o condão de encerrar essa fase, trata-se de interlocutória, submetendo-se ao regime do agravo de instrumento, nos casos previstos expressamente na lei (art. 1.015 NCPC).

Não é outra a lição de Daniel Amorim:

Não teria mesmo sentido admitir um agravo de instrumento contra capítulo da sentença que afastou uma preliminar (questão incidente) e concomitante a esse recurso admitir a interposição de apelação contra o capítulo que acolheu ou rejeitou o pedido. Apesar da nítida diferença de natureza entre os dois capítulos decisórios, tomando-se a decisão como una e indivisível e adotando-se o caráter finalístico de conceituação dos pronunciamentos judiciais, não há como deixar de classificar a decisão com uma sentença, recorrível tão somente por apelação. ${ }^{47}$

Como demonstração inequívoca que o NCPC caminhou nesta trajetória, prevê o $\S 3^{\circ}$ do artigo 1.009 :

Da sentença cabe apelação (caput).

$\S 3^{\circ}$ - O disposto no caput deste artigo aplica-se mesmo quando as questões mencionadas no art. 1.015 integrarem capítulo da sentença.

Para elucidar, as questões mencionadas no art. 1.015 a que se refere o $\S 3^{\circ}$ são as decisões interlocutórias, que, a despeito de desafiarem, a rigor, agravo de instrumento, se proferidas no bojo de uma sentença, serão suscetíveis de apelação, unicamente.

\footnotetext{
${ }^{46}$ Informativo 523/STJ: $4^{\text {a }}$ Turma, AgRg no AREsp 9.653/SP, rel. Min. Luis Felipe Salomão, j. 02/05/2013.

${ }^{47}$ NEVES, Daniel Amorim Assumpção. Manual de direito processual civil - volume único. 8. ed Salvador: Ed. JusPodivim, 2016. p. 1.488.
} 
Mantendo-se a coerência, o NCPC dispõe no $§ 5^{\circ}$ do art. 1.013 “ $\mathrm{O}$ capítulo da sentença que confirma, concede ou revoga a tutela provisória é impugnável na apelação".

Discute-se também a respeito da outra exceção à unirrecorribilidade, que se dá quando a decisão proferida for obscura, contraditória, omissa ou que contiver erro material, o que desafia além do recurso habitual (apelação, especial etc), também os embargos de declaração (art. $1.022^{48}$ ), que deverá ser interposto no prazo de 5 (cinco) dias. Em verdade, porém, os dois recursos não são simultâneos, e sim, sucessivos, tendo cada um deles objetivos diversos, o primeiro para esclarecer e completar a decisão, o segundo para reformá-la. E mais que isso, a interposição dos declaratórios interrompe ${ }^{49}$ o prazo para a apresentação do recurso regular, e somente após a intimação do resultado de seu julgamento é que a parte disporá do prazo para o recurso próprio contra a decisão guerreada (interpõe-se um, e, após o seu julgamento, interpor-se-á outro), conforme será estudado adiante.

Por exemplo, se a decisão for uma sentença e nesta contiver motivos para os embargos de declaração, não haverá concomitância entre estes e a apelação, e confirma Humberto Theodoro Jr:

Em todas essas situações excepcionais a quebra do princípio da unirrecorribilidade provém da lei e não da vontade da parte, de sorte que, fora da permissão legal expressa, não é dado ao vencido interpor senão um recurso contra cada decisão, ou seja, o "recurso adequado", aquele indicado pela lei "para o reexame da decisão que se impugna"50

\section{$6 \quad$ PRINCÍPIO DA FUNGIBILIDADE RECURSAL}

Partindo da premissa de que a parte só poderá impugnar a decisão mediante um recurso, o que poderá ela fazer quando houver, na própria legislação, dúvida quanto ao cabimento de um ou outro recurso no caso

\footnotetext{
${ }^{48}$ Art. 1.022. CPC/15 - Cabem embargos de declaração contra qualquer decisão judicial para: I esclarecer obscuridade ou eliminar contradição; II - suprir omissão de ponto ou questão sobre o qual devia se pronunciar o juiz de ofício ou a requerimento; III - corrigir erro material.

${ }^{49}$ Art. 1.026. CPC/15 - Os embargos de declaração não possuem efeito suspensivo e interrompem o prazo para a interposição de recurso.

${ }^{50}$ THEODORO Júnior, Humberto. Curso de Direito Processual Civil - Teoria geral do direito processual civil, processo de conhecimento e procedimento comum - vol. III. 46. ed. - Rio de Janeiro: Forense, 2016. p. 958.
} 
concreto? Ficará ela à mercê do acaso, devendo interpor um dos dois recursos sobre o qual paira a dúvida e torcer para que seja admitido (rectius: tido por correto de acordo com o entendimento do juiz)?

Não. O princípio da fungibilidade veio para tutelar a parte nessas situações, resguardando-a contra eventuais incongruências da lei, vez que a parte não pode ser prejudicada em seu direito por uma falha do legislador ${ }^{51}$.

Fungibilidade é uma manifestação do princípio da instrumentalidade das formas na seara recursal, por meio da qual haverá na prática, se preenchidos alguns requisitos, a substituição ou o recebimento de um recurso por outro, a admissão do recurso nominalmente errado como se fosse o correto no caso concreto, em respeito ao aproveitamento máximo dos atos processuais e à flexibilização de procedimentos.

Expõe Daniel Neves que é certa que a "apuração técnica notada no novo CPC torna quase inexistente a confusão legal quanto a natureza da decisão. " ${ }^{52}$ De todo modo, qualquer situação causadora de incerteza quanto ao recurso cabível, seja decorrente do próprio texto legal quanto a natureza da decisão, seja porque a doutrina e jurisprudência divergem quanto ao recurso cabível, ou ainda, por falha judicial pela prolação de uma espécie de decisão no lugar de outra, abre espaço para a aplicação da fungibilidade.

\subsection{FUNGIBILIDADE RECURSAL EXPRESSA NO NCPC}

Uma importante demonstração do mens legis do Novo Código, o de prestigiar a instrumentalidade das formas no âmbito recursal, se deu com a previsão expressa de duas situações que permitem a fungibilidade entre recursos, encontradas nos artigos $1.024, \S 3^{\circ}, 1.032$ e 1.033 :

\footnotetext{
${ }^{51}$ A fungibilidade recursal sempre permeou o ordenamento jurídico pátrio. Inclusive, no CPC de 1939, constava ela de dispositivo expresso, que assim enunciava: Art. 810/CPC-39 - "Salvo a hipótese de má-fé ou erro grosseiro, a parte não será prejudicada pela interposição de um recurso por outro, devendo os autos ser enviados à Câmara, ou turma, a que competir o julgamento." (revogado). Não obstante o CPC/73 e o Novo CPC não possuam disposição expressa nesse sentido, não se pode infirmar que a fungibilidade fora afastada do ordenamento. Muito pelo contrário. Subsiste pelas mesmas razões acima citadas: a repulsa, pela própria lei, ao prejuízo do litigante por falha a ele não imputável. Também tratando do assunto: Cf. MIRANDA, Gilson Delgado; PIZZOL, Patricia Miranda. Recursos no processo civil. 6. ed. atual. São Paulo: Atlas, 2009. p. 12.

${ }^{52}$ NEVES, Daniel Amorim Assumpção. Manual de direito processual civil - volume único.8. ed Salvador: Ed. JusPodivim, 2016. p. 1.494.
} 


\subsection{4 §3ㅇ - CONVERSÃO DE EMBARGOS DE DECLARAÇÃO EM AGRAVO INTERNO}

O órgão julgador conhecerá dos embargos de declaração como agravo interno se entender ser este o recurso cabível, desde que determine previamente a intimação do recorrente para, no prazo de 5 (cinco) dias, complementar as razões recursais, de modo a ajustá-las às exigências do art. $1.021, \S 1^{\circ}$.

Este dispositivo teve evidentemente em vista corrigir jurisprudência "defensiva" e equivocada da jurisprudência, no sentido de não considerar cabível recurso de embargos de declaração contra decisões monocráticas proferidas por tribunais superiores ${ }^{53}$, na busca de uma decisão de mérito justa e efetiva para o caso concreto, evitando soluções que privilegiam apenas a forma em detrimento do conteúdo.

$\mathrm{Na}$ verdade, esta previsão nada mais fez do que estabelecer textualmente o que já vinha sendo feito pela jurisprudência, de forma pacífica, quando os embargos declaratórios tinham o evidente espeque de modificar a decisão embargada (efeito modificativo ou infringente). ${ }^{54}$

Por falta de previsão expressa no supracitado artigo, já que os embargos de declaração tem prazo diferente do agravo interno ( 5 dias e 15 dias) ${ }^{55}$, o prazo para conversão dos embargos de declaração em agravo interno será de 5 (cinco) dias, na forma do art. $218, \S 3^{\circ 56}$ do NCPC, a ser realizada pelo recorrente, complementando suas razões e adequando-as à regularidade formal exigida para o agravo interno (art. 1.02157).

\footnotetext{
${ }^{53}$ ALVIM, Teresa Arruda et al, coordenadores. Breves comentários ao Novo Código de Processo Civil. São Paulo: Ed. RT, 2015. p. 1.024.

${ }^{54}$ STJ, $4^{\circ}$ T, EDclREsp 1338937-PR, rel. Min. Luis Felipe Salomão, j. 3.4.2014, DJUE 11.04.2014 / EDcl no AREsp 399.852/RJ, Rel. Min. Eliana Calmon, 2 ${ }^{\mathrm{a}}$ T., j. 17.12.2013, DJe 07.02.2104.

${ }^{55}$ Art. 1.003. CPC/15 - O prazo para interposição de recurso conta-se da data em que os advogados, a sociedade de advogados, a Advocacia Pública, a Defensoria Pública ou o Ministério Público são intimados da decisão. $\S 5^{\circ}$ Excetuados os embargos de declaração, o prazo para interpor os recursos e para responder-lhes é de 15 (quinze) dias. (grifo nosso)

${ }^{56}$ Art. 218. CPC/15 - Os atos processuais serão realizados nos prazos prescritos em lei. § $3^{\circ}$ Inexistindo preceito legal ou prazo determinado pelo juiz, será de 5 (cinco) dias o prazo para a prática de ato processual a cargo da parte.

${ }^{57}$ Art. 1.021. CPC/15 - Contra decisão proferida pelo relator caberá agravo interno para o respectivo órgão colegiado, observadas, quanto ao processamento, as regras do regimento interno do tribunal. § $1^{\circ}$ Na petição de agravo interno, o recorrente impugnará especificadamente os fundamentos da decisão agravada. $\S 2$ o $\mathrm{O}$ agravo será dirigido ao relator, que intimará o agravado para manifestar-se sobre o recurso no prazo de 15 (quinze) dias, ao final do qual, não havendo retratação, o relator levá-lo-á a julgamento pelo órgão colegiado, com inclusão em pauta. § $3^{\circ}$ É vedado ao relator limitar-se à reprodução dos fundamentos da decisão agravada para julgar improcedente o agravo interno. $\S 4^{\circ}$ o Quando o agravo interno for declarado manifestamente inadmissível ou improcedente em votação
} 
Posteriormente deverá o agravado ser intimado para promover o contraditório.

\subsubsection{ARTIGOS 1.032 E 1.033 - CONVERSÃO DE RECURSO ESPECIAL EM EXTRAORDINÁRIO E VICE-VERSA}

Alternativa elogiável e marcante do NCPC, que contraria toda a jurisprudência formada até então que considerava a utilização errônea destes recursos como erro grosseiro ${ }^{58}$, motivo pelo qual afastava a incidência da fungibilidade. Como será estudado com minúcia adiante, a grosso modo, recurso especial serve para combater decisão que afronta as regras infraconsticucionais e recurso extraordinário contra decisão que contraria a Constituição. Destarte, sob a vigência código revogado, se a parte interpusesse recurso especial para combater decisão ofensiva à Constituição ou ao contrário, recurso extraordinário cuidando de matéria infraconstitucional, a tendência jurisprudencial era de não recebimento destes recursos.

Já no formato do NCPC, art. 1.032 consta:

Se o relator, no Superior Tribunal de Justiça, entender que o recurso especial versa sobre questão constitucional, deverá conceder prazo de 15 (quinze) dias para que o recorrente demonstre a existência de repercussão geral e se manifeste sobre a questão constitucional.

Parágrafo único. Cumprida a diligência de que trata o caput, o relator remeterá o recurso ao Supremo Tribunal Federal, que, em juízo de admissibilidade, poderá devolvê-lo ao Superior Tribunal de Justiça.

Na sequência, o art. 1.033 dispõe que:

Se o Supremo Tribunal Federal considerar como reflexa a ofensa à Constituição afirmada no recurso extraordinário, por pressupor a revisão da interpretação de lei federal ou de tratado, remetê-lo-á ao Superior Tribunal de Justiça para julgamento como recurso especial.

unânime, o órgão colegiado, em decisão fundamentada, condenará o agravante a pagar ao agravado multa fixada entre um e cinco por cento do valor atualizado da causa. § 5ㅇ A interposição de qualquer outro recurso está condicionada ao depósito prévio do valor da multa prevista no § 4oa à exceção da Fazenda Pública e do beneficiário de gratuidade da justiça, que farão o pagamento ao final.

${ }^{58}$ STJ, $2^{\text {a }}$ T, AgRg no AREsp 571.026/PE, rel. Min. Mauro Campbell Marques, j. 21/10/2014, DJe 28/10/2014. 
Desta maneira a mudança foi radicalmente no sentido contrário ao que dispunha a jurisprudência formada a partir do Código de 1973, com manifesto prestígio ao conteúdo em detrimento da forma, conduta que favorece o jurisdicionado, que verá o seu recurso, se preenchidos os demais requisitos legais, ser julgado pela corte competente, a despeito de não ter atendido, in totum, o princípio da taxatividade, com vistas à valorização sobremaneira do acesso à justiça.

Imprescindível realçar que, tirando essas duas exceções textualmente previstas no NCPC, para que possa ser aplicado o princípio da fungibilidade, alguns requisitos devem ser observados, nos termos da configuração jurisprudencial ${ }^{59}$, conforme a seguir.

\subsection{REQUISITOS PARA APLICAÇÃO DA FUNGIBILIDADE RECURSAL FORA DAS DUAS SITUAÇÕES PREVISTAS NO TEXTO LEGAL}

a) "dúvida objetiva e fundada" acerca de qual o recurso a ser interposto;

A "dúvida objetiva e fundada” é aquela que não parte do sujeito que a interpreta, mas sim do próprio texto da lei, de tal modo que qualquer pessoa, ao interpretá-la, incidiria na mesma dúvida. A dúvida reside no texto, no objeto - daí "objetiva" - e não no íntimo de determinado indivíduo (caso contrário seria "dúvida subjetiva", que não admite a fungibilidade). Pode a dúvida se originar de imprecisão dos termos da lei, de divergência doutrinária quanto à natureza do pronunciamento ou da circunstância de o juiz proferir um pronunciamento em lugar de outro ${ }^{60}$.

b) inexistência de erro grosseiro;

O "erro grosseiro" é um requisito que se pode ter por redundante. Não há como o recorrente incidir em erro inescusável ou crasso se há controvérsia sobre o tema, ou seja, se há dúvida objetiva o erro não será grosseiro.

c) não-configuração de má-fé da parte;

A má-fé deve ser repelida não só no que atine ao princípio da fungibilidade, mas em todo e qualquer ato processual, em respeito ao

\footnotetext{
${ }^{59}$ STJ, $2^{\mathrm{a}}$ T., AgRg no REsp 1.012.086/RJ, rel. Min. Humberto Martins, j. 25.08.2009, DJe 16.09.2009. ${ }^{60}$ GONÇALVES, Marcus Vinicius Rios. Novo curso de direito processual civil, volume 2: processos de conhecimento ( $2^{\mathbf{a}}$ parte) e procedimentos especiais. 3. ed. rev. e atual. São Paulo: Saraiva, 2007. p. 74 .
} 
princípio da boa-fé processual, que também se aplica in casu. Portanto, apesar de a jurisprudência citá-lo como requisito, tem-se por pressuposto implícito de qualquer ato, sendo, a nosso ver, desnecessária sua enunciação.

d) que a interposição do recurso tenha sido realizada no prazo em que deveria ter sido interposto o recurso correto.

Quanto ao requisito de que seja interposto no prazo do recurso tido por correto, é exigência que a doutrina majoritária tem por descabida. Nesse sentido, José Miguel Medina afirma "isso porque, a rigor, caso se negue o direito de o recorrente interpor o recurso $\mathrm{x}$ no prazo do recurso $\mathrm{x}$, exigindo que o faça no prazo (menor) do recurso $y$, não se estaria aplicando, totalmente, o princípio da fungibilidade" 61 . A parte, no mais das vezes, perderia o direito de recorrer, não em razão de negligência sua que a fizesse perder o prazo, mas sim em virtude de incongruência da lei, o que é inadmissível. ${ }^{62}$

No entanto, importante ressaltar que, apesar da forte crítica da doutrina, a jurisprudência ainda oscila no sentido de que deve ser interposto no prazo do recurso correto $^{63}$, podendo prevalecer, assim, esta última, posição que, a nosso ver, se encontra em total descompasso com a aplicação do instituto.

É patente que o advogado deve conhecer o direito e saber distinguir entre decisão interlocutória e sentença, mas também é obrigação do Judiciário decidir de modo a não gerar qualquer dúvida, seja quanto ao veredicto posto, seja em relação à condução do processo, não sendo justo

\footnotetext{
${ }^{61}$ MEDINA, José Miguel Garcia; WAMBIER, Teresa Arruda Alvim. Recursos e ações autônomas de impugnação. São Paulo: Editora Revista dos Tribunais, 2008, p. 65-66.

${ }^{62}$ Nesta concepção, algumas decisões que vêm admitindo a aplicação do princípio da fungibilidade independente do requisito da tempestividade (RSTJ 30/474 e RT 127/244). Da mesma forma, alguns processualistas de renome, como Tereza Arruda Alvim e Nelson Nery Júnior, defendem a tese de que a intempestividade não pode ser motivo para a rejeição da incidência do princípio da fungibilidade, pois, se o erro é justificável, a fungibilidade valida à impugnação segundo os requisitos do recurso interposto. Outrossim, Nery Jr. afirma que não se pode exigir do recorrente que se valha de prazo menor do recurso que não aviou, pois havendo dúvida objetiva, a parte, por uma questão lógica, irá observar o prazo do recurso efetivamente interposto. "a regra da fungibilidade é ditada no interesse da parte". ${ }^{63}$ Processual civil. Execução fiscal. Valor inferior a 50 ORTNs. Reexame necessário. Descabimento. Recurso de apelação. Inadequação da via processual eleita. Cabimento de embargos infringentes Princípio da fungibilidade. Inaplicabilidade, pelo decurso de prazo superior ao previsto no art. 34 da LEF. 1. Contra as sentenças proferidas nas execuções fiscais cujo valor é inferior ao quantum fixado pelo art. 34, caput, da LEF, são cabíveis, apenas, embargos infringentes e de declaração. 2. O princípio da fungibilidade recursal determina o recebimento de uma espécie pela outra, desde que não haja outros óbices, como, no caso, o decurso de prazo superior àquele de que dispunha o recorrente para o manejo dos embargos de devedor 3. Recurso especial desprovido. (STJ, $1^{\text {a }}$ T., REsp 413.827/PR, rel. Min. Teori Albino Zavascki, j. 06.05.2004, DJ 24/05/2004 p. 158.) [grifo nosso]
} 
imputar somente ao advogado a responsabilidade pelo erro quando de certo modo, também a máquina judiciária concorreu para que se verificasse ${ }^{64}$.

Vale dizer que, se houve dúvida objetiva oriunda do texto legal, fazendo com que o advogado utilize um recurso em vez de outro (com prazo menor), não seria condizente com a fungibilidade a exigência de que a via recursal eleita de forma errônea se desse no prazo do recurso correto. Até porque se não emergisse dúvida do texto legal, o advogado teria utilizado o recurso certo, e, portanto, no prazo certo (menor).

Enfim, recomenda-se ao recorrente, quando do ajuizamento da petição recursal, havendo "dúvida objetiva" acerca de qual o recurso adequado, preliminarmente, requerer que seja ele tido por outro ${ }^{65}$, caso se entenda que não é o correto para o caso, o que deverá ser instruído com fundamentação relevante ou jurisprudência que ateste a existência da dúvida. Ainda, como vimos, a prudência recomenda que seja o recurso interposto no menor prazo dentre os previstos para os recursos sobre os quais paira a controvérsia, a fim de que seja tido por tempestivo, para evitar-se o risco de seu não recebimento, em observância ao entendimento jurisprudencial ainda dominante.

Como fecho, adota-se aqui a objetiva lição de Humberto Theodoro $\mathrm{Jr}^{66}{ }^{6}$ que instrui que "na realidade um único requisito se devia exigir para incidência do princípio da fungibilidade em matéria de recurso: o da dúvida objetiva e fundada, como aliás se pode notar em acórdãos recentes do STJ". ${ }^{67}$

Independentemente da falta de regra específica no NCPC sobre a fungibilidade, como ocorria no código anterior, é certo que esse princípio deve ser aplicado em submissão a outros princípios ínsitos ao novo

\footnotetext{
${ }^{64}$ Cf. Décima Sexta Câmara Cível do Tribunal de Justiça do Paraná, AC2328138 PR, apelação cível 0232813-8, que remete à decisão do STJ: Aplica-se no caso o princípio da fungibilidade, uma vez presente dúvida objetiva a respeito do recurso cabivel, e também por incorrer erro grosseiro e má-fé, sendo dispensável o pressuposto do prazo menor como requisito. (STJ, $4^{\mathrm{a}}{ }^{\mathrm{T}}$ T., REsp 113.443/PR rel. Min. (p/o Ac.) Min. Sálvio de Figueiredo Teixeira, j. 11.12.2001, DJ 01.07.2004, p. 195). (grifo nosso)

${ }^{65} \mathrm{Em}$ atenção ao princípio da fungibilidade recursal e ao requerimento sucessivo do agravante, embargos de declaração recebidos como agravo regimental, ante o seu nítido caráter infringente (STJ, $5^{a}$ T., AgRg no REsp 883.885/PI, rel. Min. Félix Fischer, j. 09.08.2007, DJ 17.09.2007, p.347) (grifo nosso)

${ }^{66}$ THEODORO JÚNIOR, Humberto. Curso de Direito Processual Civil - Teoria geral do direito processual civil, processo de conhecimento e procedimento comum - vol. III. 46. ed. - Rio de Janeiro: Forense, 2016. p. 959.

${ }^{67}$ STJ, Corte especial, AgRg no RO nos EDcL no AgRg no MS 10.652/DR,Rel.Min. Ari Pargendler, ac. 12.04.2010, DJe 02.05.2010. Na mesma linha decidiram: STJ, $1^{\mathrm{a}}{ }^{\mathrm{T}}$., (EDcL no REsp 1.106.143/MG, DJe 26.03.2010); $2^{\mathrm{a}} \mathrm{T} .,\left(\mathrm{AgRg}\right.$ no REsp 599.458/RS, DJe 11.11.2009), $3^{\mathrm{a}} \mathrm{T}$.(AgRg no REsp 1.067.946/RN, Dje 07.12.2010) e $4^{\text {a }}$ T.(REsp 1.035.169/BA, DJe 08.02.2010).
} 
instrumento processual, como o da efetividade e aproveitamento máximo dos atos processuais.

\section{$7 \quad$ PRINCÍPIO DA DIALETICIDADE}

São sinônimos de dialética: discussão, debate, diálogo, exposição etc. É uma forma de buscar a verdade por meio da argumentação lógica e que permite, a partir do debate, da troca de ideias, que se chegue a uma conclusão. Sob o prisma recursal - e até mesmo de todo o processo - é a exigência de que a parte não apenas expresse sua irresignação com a situação processual que lhe é desfavorável, mas a realize de forma motivada, permitindo a resposta da parte contrária. Se não houver a devida fundamentação, há o impedimento de que a parte contrária possa responder os argumentos, resultando na afronta ao contraditório.

Em outras palavras, de acordo com esse princípio, não basta que o recorrente apenas manifeste o seu inconformismo com a decisão, exteriorizando sua vontade de recorrer, mas também que demonstre, desde logo, as razões de seu inconformismo, expondo por que a decisão the traz algum prejuízo e por que deve ela ser anulada ou reformada ${ }^{68}$.

É clara a correspondência do princípio em análise com o art. 319, inciso III do NCPC, que enuncia como um dos requisitos da petição inicial que a parte exponha "o fato e os fundamentos jurídicos do pedido". Se o recorrente não expõe os motivos de seu inconformismo, assim como ocorre com a petição inicial, inepta será a petição recursal.

Ainda, se o recorrente se limitar a reiterar os fundamentos da inicial, sem atacar diretamente o obstáculo criado pela decisão frente à sua pretensão, inepto será o recurso. Ex. o autor busca a condenação do réu em entregar um bem móvel, tendo o pedido por base um contrato de compra e venda. $\mathrm{O}$ juiz extingue o processo sem julgamento de mérito, com o fundamento de que o réu é parte ilegítima. De nada adiantará o autor recorrer, pleiteando a condenação do réu, sem antes derrubar a ilegitimidade ad causam com a qual o juiz fundamentou a sentença.

A Súmula 182/STJ é exemplo da presença do princípio no ordenamento brasileiro, ao esclarecer que "é inviável o agravo do art. 545 do CPC que deixa de atacar especificamente os fundamentos da decisão

\footnotetext{
${ }^{68}$ ORIONE Neto, Luiz. Recursos cíveis. 2. ed. São Paulo: Saraiva, 2006. p. 215.
} 
agravada". Anote-se apenas uma retificação. O verbete sumular, editado sob a égide do CPC/73 se refere agora ao art. 1.021/NCPC, que prevê o cabimento do agravo interno contra decisão proferida pelo relator. A redação sumular, todavia, subsiste compatível com a nova ordem jurídica processual.

Na prática, tal princípio se revela em vários artigos sobre os recursos em espécie, quando indicam que entre os requisitos da petição recursal há necessidade de motivação, por exemplos: a) apelação - art. 1.010, III (as razões do pedido de reforma ou de decretação de nulidade); b) agravo de instrumento - art. 1.016, III (as razões do pedido de reforma ou de invalidação da decisão e o próprio pedido); c) embargos de declaração - art. 1.023 (Os embargos serão opostos, no prazo de 5 (cinco) dias, em petição dirigida ao juiz, com indicação do erro, obscuridade, contradição ou omissão, e não se sujeitam a preparo); d) recurso especial e extraordinário - art. 1.029, III (as razões do pedido de reforma ou de invalidação da decisão recorrida), entre outras disposições atinentes aos demais recursos. (grifo nosso)

$\mathrm{O}$ recorrente deve indicar no que consiste a injustiça ou ilegalidade da decisão, e, nesta senda, se faltar à fundamentação (que permita o diálogo que dá com as contrarrazões do recorrido), o recurso não será admitido, conforme demonstra farta jurisprudência. ${ }^{69}$

No novo diploma processual essa necessidade de motivação das razões no exercício do direito de recorrer atende também ao princípio da cooperação estampado no art. $6^{\circ 70}$, além dos artigos $9^{\circ}$ e $10^{71}$, que exigem sempre o debate e ampla manifestação das partes antes de uma decisão judicial.

É de se observar, porém, que a motivação está inserida numa categoria de norma fundamental uma vez que ela é exigível não somente às partes, desde a petição inicial (art. 319, III: o fato e os fundamentos

\footnotetext{
${ }^{69}$ STF, $1^{\text {a }}$ T., RE 88.372/BA, Rel.Min. Bilac Pinto, ac. 24.11.1997, RTJ 85/722; STJ, $4^{\text {a }}$ T., RMS 751/GO, Rel.Min. Sálvio de Figueiredo, ac. 09.04.1991, DJU 13.05.1991, P. 6.048; STJ, $3^{\mathrm{a}}{ }^{\mathrm{T}}$., AgRg no REsp 1.241.594/RS, Rel.Min. Sidnei Beneti, ac. 21.06.2011, DJe 27.06.2011.

${ }^{70}$ Art. 6 - CPC/15 - Todos os sujeitos do processo devem cooperar entre si para que se obtenha, em tempo razoável, decisão de mérito justa e efetiva.

${ }^{71}$ Art. 9ํㅡㄹ $\mathrm{CPC}$ - Não se proferirá decisão contra uma das partes sem que ela seja previamente ouvida. Parágrafo único. O disposto no caput não se aplica: I - à tutela provisória de urgência; II - às hipóteses de tutela da evidência previstas no art. 311, incisos II e III; III - à decisão prevista no art. 701.

Art. 10. CPC/15 - O juiz não pode decidir, em grau algum de jurisdição, com base em fundamento a respeito do qual não se tenha dado às partes oportunidade de se manifestar, ainda que se trate de matéria sobre a qual deva decidir de ofício.
} 
jurídicos do pedido), mas para o juiz e tribunal a partir da obrigação da profunda e detalhada fundamentação das decisões judiciais, que têm que apreciar um a um os argumentos das partes, entre outros elementos perceptíveis no artigo $489, \S 1^{\circ}$, I a VI do NCPC ${ }^{72}$.

Em conclusão, oportuna a transcrição das súmulas do STJ e do STF, que a despeito de terem sido emitidas na vigência do código anterior, permanecem em plena vigência quanto à dialeticidade:

Súmula no 287 do STF: "Nega-se provimento ao agravo, quando a deficiência em sua fundamentação, ou no do recurso extraordinário, não permitir a exata compreensão da controvérsia".

Súmula no 284 do STF: "É inadmissível o recurso extraordinário, quando a deficiência na sua fundamentação não permitir a exata compreensão da controvérsia".

Súmula no 282 do STF: "É inadmissível o recurso extraordinário quando não ventilada, na descisão recorrida, a questão federal suscitada".

Súmula no 126 do STJ: "É inadmissível o recurso especial, quando o acordão recorrido assenta em fundamentos constitucional e infraconstitucional, qualquer deles suficiente, por si só, para mantê-lo, e a parte vencida não manifesta recurso extraordinário".

Súmula no 182 do STJ: "É inviável o agravo do art. 545 do CPC que deixa de atacar especificamente os fundamentos da decisão agravada".

\section{PRINCÍPIO DA PROIBIÇÃO DA REFORMATIO IN PEJUS}

\footnotetext{
${ }^{72}$ Art. 489. CPC/15 - São elementos essenciais da sentença: I - o relatório, que conterá os nomes das partes, a identificação do caso, com a suma do pedido e da contestação, e o registro das principais ocorrências havidas no andamento do processo; II - os fundamentos, em que o juiz analisará as questões de fato e de direito; III - o dispositivo, em que o juiz resolverá as questões principais que as partes lhe submeterem. $\S 1^{\circ}$ Não se considera fundamentada qualquer decisão judicial, seja ela interlocutória, sentença ou acórdão, que: I - se limitar à indicação, à reprodução ou à paráfrase de ato normativo, sem explicar sua relação com a causa ou a questão decidida; II - empregar conceitos jurídicos indeterminados, sem explicar o motivo concreto de sua incidência no caso; III - invocar motivos que se prestariam a justificar qualquer outra decisão; IV - não enfrentar todos os argumentos deduzidos no processo capazes de, em tese, infirmar a conclusão adotada pelo julgador; V - se limitar a invocar precedente ou enunciado de súmula, sem identificar seus fundamentos determinantes nem demonstrar que o caso sob julgamento se ajusta àqueles fundamentos; VI - deixar de seguir enunciado de súmula, jurisprudência ou precedente invocado pela parte, sem demonstrar a existência de distinção no caso em julgamento ou a superação do entendimento. (grifo nosso)
} 
Na lição de Theodoro Jr., o Código de Processo Civil de 1939 "continha regra expressa vedando a reforma da decisão recorrida para piorar a situação jurídica do recorrente, sem que a outra parte também tivesse recorrido." Continua o referido mestre, afirmando que o CPC/73 "não reproduziu a norma, mas o preceito continua vigente por força do princípio inerente ao sistema estrutural do processo de prestação jurisdicional" "73. Assim também o é no Novo CPC. Embora não se tenha positivado a impossibilidade de reformatio in pejus, esta disposição que veda o agravamento da situação da parte recorrente, sem que a outra parte também tenha recorrido, decorre da lógica do sistema processual.

Nesse cenário, é vedada a reforma da decisão para piorar a situação do recorrente: ou a sua situação se mantém como está, ou melhora. Em outros termos, ninguém poderá ter sua condenação agravada em razão do seu próprio recurso, haja vista que quanto à parte da decisão que lhe foi favorável opera-se o trânsito em julgado (por falta de recurso da parte contrária).

O recorrente, já na petição recursal, demarca quais serão os limites objetivos do recurso, ou seja, é ele quem decide quais as questões que pretende ver reformadas. $\mathrm{O}$ juiz ficará adstrito a julgar essas questões e nos limites traçados pelo recorrente, não podendo piorar a sua situação, salvo no que se refere às matérias de ordem pública ${ }^{74}$, que poderão ser analisadas a qualquer tempo e ex officio. Quanto a essas, o juiz poderá julgar agravando a situação daquele, caracterizando-se como única exceção ao princípio em comento.

Imperioso aqui lembrar o novo art. 10 do $\mathrm{CPC}$, que, em homenagem ao contraditório pleno, impõe que, mesmo na hipótese de tratar-se de matéria de ordem pública, o juiz ou tribunal tem que oportunizar à parte a manifestação, in verbis: "O juiz não pode decidir, em grau algum de jurisdição, com base em fundamento a respeito do qual não se tenha dado às partes oportunidade de se manifestar, ainda que se trate de matéria sobre a qual deva decidir de ofício". (grifo nosso)

O princípio da non reformatio in pejus decorre do princípio dispositivo, que consiste em nada mais que limitar o órgão julgador a só agir quando provocado (art. $2^{075}$ ) e, ainda, que restrinja a sua atuação ao pedido da parte. Considera também o princípio da congruência verificável

\footnotetext{
${ }^{73}$ THEODORO JÚNIOR, Humberto. Curso de direito processual civil. v.1. Rio de Janeiro: Forense, 2009. p. 634.

${ }^{74}$ Pressupostos processuais, condições da ação, decadência, prescrição, entre outras.

${ }^{75}$ Art. $2^{\circ} \mathrm{CPC} / 15$ - o processo começa por iniciativa da parte (...)
} 
nos arts. $141^{76}$ e $492^{77}$, de forma que a decisão não seja ultra, citra ou extra petita. Sendo assim, não poderá o recorrente ter sua situação agravada e nem o recorrido beneficiar-se do recurso interposto pela parte contrária ${ }^{78}$.

A título de exemplo, em uma causa relativa a seguro de responsabilidade civil perante terceiros, o juiz fixa, em primeiro grau, a indenização em vinte mil reais por danos materiais. A parte, inconformada, pretendendo o valor de cinquenta mil, interpõe recurso. Sendo ele julgado procedente ou improcedente, o mínimo que a parte levará será vinte mil reais, uma vez que não pode ser piorada a sua situação. No entanto, se o tribunal, ao apreciá-lo, perceber que o direito se encontra prescrito (matéria de ordem pública ${ }^{79}$, poderá ele retirar o direito do recorrente à reparação, inclusive quanto àqueles vinte mil reais que já lhe eram devidos.

Nesta concepção, repita-se que, pela via da exceção, as questões de ordem pública (condições da ação, pressupostos processuais, requisitos de admissibilidade dos recursos etc.), na forma dos artigos $485, \S 3^{\circ 80}$, e $337, \S 5^{\circ}$ do $\mathrm{NCPC}^{81}$ quando evidenciadas, poderão ser conhecidas e julgadas a qualquer tempo, independentemente de provocação das partes, o que poderá agravar a situação do recorrente, nas restritas hipóteses de sua ocorrência.

Por outro lado, não se pode alegar que há reformatio in pejus quando ambos os litigantes interpõem recurso, na hipótese de sucumbência recíproca, uma vez que ambos têm o direito de pleitear a melhora de sua situação e, inegavelmente, a melhora para um resultará na piora para o outro. Explicando de forma simples, na hipótese da outra parte também

\footnotetext{
${ }^{76}$ Art. 141. CPC/15 - O juiz decidirá o mérito nos limites propostos pelas partes, sendo-lhe vedado conhecer de questões não suscitadas a cujo respeito a lei exige iniciativa da parte.

${ }^{77}$ Art. 492. CPC/15 - É vedado ao juiz proferir decisão de natureza diversa da pedida, bem como condenar a parte em quantidade superior ou em objeto diverso do que lhe foi demandado. Parágrafo único. A decisão deve ser certa, ainda que resolva relação jurídica condicional.

${ }^{78}$ MIRANDA, Gilson Delgado; PIZZOL, Patrícia Miranda. Recursos no processo civil. 6. ed. atual. São Paulo: Atlas, 2009. p. 14.

${ }^{79}$ Art. 487, II, CPC/15 - Haverá resolução do mérito quando o juiz: II - decidir, de ofício ou a requerimento, sobre a ocorrência de decadência ou prescrição.

${ }^{80}$ Art. $485, \S 3^{\circ} \mathrm{CPC} / 15$ - O juiz conhecerá de ofício da matéria constante dos incisos IV, V, VI e IX, em qualquer tempo e grau de jurisdição, enquanto não ocorrer o trânsito em julgado. (IV - verificar a ausência de pressupostos de constituição e de desenvolvimento válido e regular do processo; V reconhecer a existência de perempção, de litispendência ou de coisa julgada; VI - verificar ausência de legitimidade ou de interesse processual; IX - em caso de morte da parte, a ação for considerada intransmissível por disposição legal.)

${ }^{81}$ Art. $337, \S 5^{\circ} \mathrm{CPC} / 15$ - Excetuadas a convenção de arbitragem e a incompetência relativa, o juiz conhecerá de ofício das matérias enumeradas neste artigo.
} 
recorrer, a situação das duas correrá o risco de ser piorada, mas obviamente não através de seu próprio recurso, mas do recurso da outra.

Outra situação notável é a que se encontra prevista no art. 1.013, $\S 3^{\circ}$ do $\mathrm{NCPC}^{82}$. Nela, se o tribunal entender por alterar a sentença de extinção do processo sem análise do mérito (art. $485^{83}$ ), poderá avançar ao mérito desde que o processo esteja em condições de julgamento. Ainda que o autor tenha recorrido da sentença com vistas à sua modificação para atender seu pedido de procedência, pode ocorrer que o tribunal julgue no mérito pela improcedência dos pedidos lançados na petição inicial. Neste caso, o autor que tinha contra si uma decisão de extinção do seu processo (desfavorável, portanto), terá agora, por provocação de seu próprio recurso, uma decisão de mérito também desfavorável, mas não em desobediência ao non reformatio in pejus, mas pelos desdobramentos previstos na lei que permitem que todas as questões debatidas nos autos devem ser apreciadas pelo tribunal, o que pode resultar em resolução do mérito em favor ou em prejuízo do autor.

Ainda no campo das peculiaridades, adota-se nesta a percepção de Fredie Didier Jr. e Leonardo Carneiro da Cunha:

É preciso ponderar, no entanto, que, de acordo com o sistema do CPC-2015, é possível a majoração dos honorários advocatícios na instância recursal (art.85, s 11, CPC). Assim, é possível que o recorrente tenha a sua situação piorada após o julgamento do recurso, em razão do aumento da condenação ao pagamento de honorários advocatícios. Note, porém, que o agravamento da situação do recorrente ocorrerá apenas nessa parte; em relação ao

\footnotetext{
${ }^{82}$ Art. 1.013. CPC $/ 15-\S 3^{\circ}$ Se o processo estiver em condições de imediato julgamento, o tribunal deve decidir desde logo o mérito quando: I - reformar sentença fundada no art. 485; II - decretar a nulidade da sentença por não ser ela congruente com os limites do pedido ou da causa de pedir; III - constatar a omissão no exame de um dos pedidos, hipótese em que poderá julgá-lo; IV - decretar a nulidade de sentença por falta de fundamentação.

${ }^{83}$ Art. 485 CPC/15 - O juiz não resolverá o mérito quando: I - indeferir a petição inicial; II - o processo ficar parado durante mais de 1 (um) ano por negligência das partes; III - por não promover os atos e as diligências que lhe incumbir, o autor abandonar a causa por mais de 30 (trinta) dias; IV - verificar a ausência de pressupostos de constituição e de desenvolvimento válido e regular do processo; V reconhecer a existência de perempção, de litispendência ou de coisa julgada; VI - verificar ausência de legitimidade ou de interesse processual; VII - acolher a alegação de existência de convenção de arbitragem ou quando o juízo arbitral reconhecer sua competência; VIII - homologar a desistência da ação; IX - em caso de morte da parte, a ação for considerada intransmissível por disposição legal; e X - nos demais casos prescritos neste Código.
} 
capítulo da decisão que fora recorrido, ao tribunal cabe apenas mantê-lo ou revê-lo (total ou parcialmente) ${ }^{84}$

Por fim, cumpre ressaltar que, também com fundamento nos princípios do dispositivo e da congruência, não é admitida a reformatio in melius, isto é, a reforma da decisão para melhorar a situação do recorrente além do que foi pedido ${ }^{85}$.

Súmula aplicável (n ${ }^{\circ} 45$ STJ de 26/10/2015): No reexame necessário é defeso, ao Tribunal, agravar a condenação imposta à Fazenda Pública.

\section{9 \\ PRINCÍPIO DA AMPLA DEFESA E CONTRADITÓRIO}

O princípio da ampla defesa ${ }^{86}$ e contraditório é decorrência do princípio da isonomia processual ${ }^{87}$. Se ao autor é permitido postular em juízo a sua pretensão, ao réu há de ser dada a possibilidade de se defender contra esta; de provar, em juízo, a improcedência do pedido do autor. O princípio se traduz em garantia constitucional, outorgada ao cidadão pelo art. $5^{\circ}$, inc. LV da Constituição Federal ${ }^{88}$. A sua não-observância resulta em ofensa ao due process of law, viciando todos os atos processuais em que não fora atendido.

No que concerne à sistemática recursal, sua importância é ainda maior, vez que, se não for dada ao vencido a oportunidade de impugnar uma decisão final do julgador, transitará ela em julgado, tornando-se imutável.

\footnotetext{
${ }^{84}$ DIDIER JR., Fredie; CUNHA, Leonardo José Carneiro da, Curso de direito processual civil: meios de impugnação às decisões judiciais. $5^{\mathrm{a}}$.ed. Salvador: JusPodivm, 2008. p.139.

${ }^{85}$ DONIZETTI, Elpídio. Curso didático de direito processual civil. 19 ed. rev. e completamente reformulada conforme o Novo CPC - Lei 13.105, 16 de março de 2015 e atualizada com a Lei 13.256, de 04 de fevereiro de 2016. - São Paulo: Atlas, 2016. p. 1.425.

${ }^{86}$ A respeito, Cretella Neto aduz que a ampla defesa é conceito antigo na História da humanidade, remetendo à fala de Nicodemos no julgamento de Jesus Cristo: "Por ventura condena a nossa lei um homem sem primeiro ouvir e ter conhecimento do que faz? (Evangelho de São João 7,51)" - Cf. CRETELLA NETO, José. Fundamentos principiológicos do processo civil. Rio de Janeiro: Forense, 2002. p. 61.

${ }^{87}$ Cf. THEODORO JÚNIOR, Humberto. Curso de direito processual civil. v.1. Rio de Janeiro: Forense, 2009. p. 495.

${ }^{88}$ Art. $5^{\circ}$, LV/CF - Aos litigantes, em processo judicial ou administrativo, e aos acusados em geral são assegurados o contraditório e ampla defesa, com os meios e recursos a ela inerentes;
} 
O ordenamento é tão rigoroso quanto à sua obrigatoriedade que, ainda no caso de não ser atendido e ocorrendo o trânsito em julgado da decisão, permitir-se-á ao prejudicado, no prazo de dois anos, ajuizar ação rescisória para desfazer a grave ofensa a este imperioso pilar do Direito, com fulcro no art. 966, V/NCPC ${ }^{89}$.

Concedida à oportunidade, fica ao alvedrio do vencido recorrer ou não. No entanto, caso não o faça e se sinta por tanto prejudicado, será o gravame decorrente de sua conduta ${ }^{90}$, e não do sistema que não o teria protegido contra uma decisão injusta.

\section{PRINCÍPIO DA VOLUNTARIEDADE}

Como visto anteriormente, recurso é um direito, mas também a sua não interposição carrega em si um ônus, que é a submissão do vencido ao cumprimento da decisão, que se encontrará revestida do manto da res iudicata, e, portanto, imutável. De toda forma, nada há de ser feito pela autoridade judiciária com o processo se a parte optar por não lançar mão da via recursal, para que não haja violação ao caráter dispositivo do direito de ação, aplicável do mesmo modo aos recursos. Estudou-se também que o juiz ou tribunal tem que se limitar ao princípio da congruência, não podendo exceder os limites da pretensão das partes.

Conforme essa ideia, se não houver provocação recursal pela parte, é impossível que se opere a apreciação pelo tribunal do que fora julgado, e, ainda mais se a situação for analisada sob as luzes de vários artigos do NCPC, nos quais a percepção da voluntariedade fica nítida: art. 141 - "O juiz decidirá o mérito nos limites propostos pelas partes, sendolhe vedado conhecer de questões não suscitadas a cujo respeito a lei exige iniciativa da parte”. Art. 996 - "O recurso pode ser interposto...". Art. 1.002: "A decisão pode ser impugnada no todo ou em parte". Art. 1.008

\footnotetext{
${ }^{89}$ Art. 966, V, CPC/15 - A sentença de mérito, transitada em julgado, pode ser rescindida quando: violar manifestamente norma jurídica.

${ }^{90}$ Scarpinella fala no chamado "principio da voluntariedade", como "significativo da necessidade de o recorrente, isto é, aquele que detém legitimidade e interesse em recorrer (porque a decisão, tal qual proferida, trouxe-lhe algum gravame), exteriorizar o seu inconformismo com vistas a afastar o prejuizo que a decisão lhe acarreta." (BUENO, Cassio Scarpinella. Curso sistematizado de direito processual civil.: recursos, processos e incidentes nos tribunais, sucedâneos recursais: técnicas de controle das decisões jurisdicionais. São Paulo: Saraiva, 2008. p. 29/30 v. 5.)
} 
que afirma que: "O julgamento proferido pelo tribunal substituirá a decisão impugnada no que tiver sido objeto de recurso". (grifo nosso)

Não há dúvida que a interposição de recursos exige a iniciativa da parte (ou do Ministério Público ou do terceiro prejudicado - art. 996 ${ }^{91}$ ), uma vez que somente esses são os legitimados pela lei para requererem a alteração do julgado. Da mesma forma, o tribunal não julgará o recurso, se houver desistência dele pela parte (art. 99892).

Nos dizeres de Barbosa Moreira:

Se a omissão em recorrer mantém esse caminho totalmente fechado, a limitação voluntária do âmbito do recurso deve logicamente mantê-lo parcialmente fechado. Abre-se o caminho na medida em que se impugna a decisão, mas somente nessa medida. ${ }^{93}$

Nem a remessa necessária ao tribunal das decisões desfavoráveis aos órgãos públicos listados no art. 496, $\mathrm{I}^{94}$ do NCPC reflete alguma forma de "recurso de ofício", uma vez que tal instituto (que será estudado adiante) é mera condição de eficácia da decisão e propositadamente não se encontra no capítulo referente aos recursos no novo CPC.

Scarpinella fala no chamado "princípio da voluntariedade", como "significativo da necessidade de o recorrente, isto é, aquele que detém legitimidade e interesse em recorrer (porque a decisão, tal qual proferida, trouxe-lhe algum gravame), exteriorizar o seu inconformismo com vistas a afastar o prejuízo que a decisão lhe acarreta. "95

\footnotetext{
${ }^{91}$ Art. 996. CPC/15 - O recurso pode ser interposto pela parte vencida, pelo terceiro prejudicado e pelo Ministério Público, como parte ou como fiscal da ordem jurídica.

92 Art. 998. CPC/15 - O recorrente poderá, a qualquer tempo, sem a anuência do recorrido ou dos litisconsortes, desistir do recurso.

${ }^{93}$ MOREIRA, Barbosa apud JORGE, Flávio Cheim. Teoria geral dos recursos cíveis. 7. ed. rev., atual. e ampl. - São Paulo: Ed. RT, 2015. p. 309.

${ }^{94}$ Art. 496. CPC/15 - Está sujeita ao duplo grau de jurisdição, não produzindo efeito senão depois de confirmada pelo tribunal, a sentença: I - proferida contra a União, os Estados, o Distrito Federal, os Municípios e suas respectivas autarquias e fundações de direito público; II - que julgar procedentes, no todo ou em parte, os embargos à execução fiscal.

${ }^{95}$ BUENO, Cassio Scarpinella. Curso sistematizado de direito processual civil.: recursos, processos e incidentes nos tribunais, sucedâneos recursais: técnicas de controle das decisões jurisdicionais. São Paulo: Saraiva, 2008. p. 29-30. v. 5.
} 


\section{1}

\section{PRINCÍPIO DA PRECLUSÃO CONSUMATIVA (CONSUMAÇÃO) OU NÃO COMPLEMENTARIDADE}

No processo civil, após a apresentação do recurso pela parte, conquanto antes do prazo final estabelecido para a interposição do mesmo, não pode ela complementar suas razões ou praticar qualquer ato de emenda ou aditamento da peça recursal, total ou parcialmente. Em outras palavras, "uma vez já exercido o direito de recorrer, consumou-se a oportunidade de fazê-lo, de sorte a impedir que o recorrente torne a impugnar o pronunciamento judicial já impugnado"96. A isso se denomina preclusão consumativa.

Do mesmo jeito, não pode o recorrente querer apresentar seu recurso após ter apresentado manifestação de desistência, mesmo que ainda dentro do prazo do recurso.

$\mathrm{Na}$ manifestação recursal a parte tem que apresentar toda a argumentação referente matéria fática e de direito. Não é admissível em processo civil, embora o seja em processo penal, protestar por futura apresentação de outras razões. ${ }^{97}$

Existe uma modalidade de recurso que, pela via da exceção, vai permitir o complemento das razões já apresentadas, conforme se depreende da leitura do $\S 4^{\circ}$ do art. 1.024 do NCPC:

Caso o acolhimento dos embargos de declaração implique modificação da decisão embargada, o embargado que já tiver interposto outro recurso contra a decisão originária tem o direito de complementar ou alterar suas razões, nos exatos limites da modificação, no prazo de 15 (quinze) dias, contado da intimação da decisão dos embargos de declaração.

Nota-se, entretanto, que, in casu, estar-se-ia falando da hipótese do manejo do recurso de embargos declaratórios por uma das partes, que na sua essência visar apenas esclarecer ou eliminar contradição de decisão (conforme será tratado a frente), e a outra, tenha apresentado o recurso próprio contra a mesma decisão (ex. apelação), após o julgamento dos embargos declaratórios com caráter modificativo ou infringente, se houver real alteração do julgado, a parte que tinha apresentado o recurso de apelação poderá aditá-lo, uma vez que a decisão por ela atacada

\footnotetext{
${ }^{96}$ NERY JUNIOR, Nelson. Teoria geral dos recursos. 5. ed. São Paulo: Ed RT. p. 164.

${ }^{97}$ Art. 578 c/c arts. 588 e 600 do Código de Processo Penal.
} 
inicialmente, sofreu alteração pelo julgamento dos embargos declaratórios propostos pela outra parte.

Se a parte interpuser um segundo recurso, a despeito de que o prazo ainda não tenha se escoado, este não será admitido, e mais, será reputado como inexistente, independentemente do resultado do primeiro, seja por ter sido redigido de forma imprópria ou porque a parte tenha eleito a via errada, e até mesmo na hipótese de que ao primeiro o julgador não tenha dado seguimento ${ }^{98}$.

\section{2 \\ PRINCÍPIO DO ÔNUS DO RECURSO OU DA SUCUMBÊNCIA RECURSAL ${ }^{99}$}

É notório que sucumbência é o princípio que revela que a parte vencida na causa tem que ressarcir todos os gastos do processo à parte vencedora, para evitar que a parte que ao final do processo tenha reconhecida sua razão tenha que suportar algum prejuízo. É a causalidade entre a resistência daquele que somente cumpriu sua obrigação após a manifestação do Poder Judiciário e não voluntariamente, e a necessidade daquele que dispendeu esforços para tanto. Do mesmo modo, essa mesma causalidade se manifesta quando alguém provoca a atuação jurisdicional sem o direito que imaginava ter, e, porquanto, deverá indenizar aquele que teve despesas processuais e de advogado para promover sua defesa.

Assim, a sentença condenará o vencido a pagar ao vencedor todas as despesas que este antecipou, além dos honorários ao advogado do vencedor, conforme arts. $82, \S 2^{\circ}$ e 85 do $\mathrm{NCPC}^{100101}$.

\footnotetext{
${ }^{98}$ STJ, $2^{\text {a }}$ Turma REsp 981.591/RS, rel. Min. Humberto Martins, j. 25.03.2008, DJe 03/04/2008.

${ }_{99}$ Para um maior aprofundamento neste tema recomendamos os escritos de CAMARGO, Luiz Henrique Volpe in ALVIM, Teresa Arruda et al, coordenadores. Breves comentários ao Novo Código de Processo Civil. São Paulo: Ed. RT, 2015. P. 321-329. E DIDIER JR., Fredie; CUNHA, Leonardo José Carneiro da, Curso de direito processual civil: meios de impugnação às decisões judiciais. $5^{\text {a }}$.ed. Salvador: JusPodivm, 2008. p. 155-159.

${ }^{100}$ Art. 82. CPC/15 - Salvo as disposições concernentes à gratuidade da justiça, incumbe às partes prover as despesas dos atos que realizarem ou requererem no processo, antecipando-lhes o pagamento, desde o início até a sentença final ou, na execução, até a plena satisfação do direito reconhecido no título. $\S 1^{\circ}$ Incumbe ao autor adiantar as despesas relativas a ato cuja realização o juiz determinar de ofício ou a requerimento do Ministério Público, quando sua intervenção ocorrer como fiscal da ordem jurídica. $\S 2^{\circ}$ A sentença condenará o vencido a pagar ao vencedor as despesas que antecipou. (grifo nosso)

${ }^{101}$ Art. 85. CPC/15 - A sentença condenará o vencido a pagar honorários ao advogado do vencedor.
} 
Uma grande novidade foi a implementação pelo legislador dos honorários nos recursos, com a possibilidade do órgão julgador elevar os honorários anteriormente fixados a esse título na sentença. Se o sujeito der causa a uma demanda originária, deverá arcar com os honorários de sucumbência. Se, de igual modo, der causa a uma demanda recursal, deverá arcar com a majoração dos honorários. ${ }^{102}$

Esta condenação deve se limitar aos que estabelecido nos parágrafos $2^{\circ}$ e $3^{\circ}$ do art. $85^{103}$. Dessa forma, se porventura o juiz tenha fixado honorários no percentual de $10 \%$ ao advogado vencedor em ação condenatória e o vencido apresentar recurso, esse percentual poderá ser majorado pelo tribunal, desde que seja respeitado o teto de $20 \%$ estabelecido no referido $\S 2^{\circ}$, em razão do trabalho adicional dispendido pela parte vencedora (recorrida) para impugnar o recurso da parte vencida (recorrente) recalcitrante, com vistas à manutenção do resultado do julgamento. Este limite se refere a cada fase do processo, ou seja, no máximo $20 \%$ na fase de conhecimento e no máximo $20 \%$ na fase de cumprimento de sentença.

Destaca-se que tal limite pode ser excedido e cumulado com multa e outras sanções processuais para punir o recorrente que agiu de forma atentatória à dignidade da justiça no decorrer do processo (cf. art. $77^{104}$ ). O que a lei protege é o direito ao duplo grau de jurisdição, mas não

102 DIDIER JR., Fredie; CUNHA, Leonardo José Carneiro da, Curso de direito processual civil: meios de impugnação às decisões judiciais. $5^{\mathrm{a}}$.ed. Salvador: JusPodivm, 2008. p.156.

${ }^{103}$ Art. 85. CPC $/ 15-\S 2^{\circ}$ Os honorários serão fixados entre o mínimo de dez e o máximo de vinte por cento sobre o valor da condenação, do proveito econômico obtido ou, não sendo possível mensurá-lo, sobre o valor atualizado da causa, atendidos: I - o grau de zelo do profissional; II - o lugar de prestação do serviço; III - a natureza e a importância da causa; IV - o trabalho realizado pelo advogado e o tempo exigido para o seu serviço. §3ำ Nas causas em que a Fazenda Pública for parte, a fixação dos honorários observará os critérios estabelecidos nos incisos I a IV do $\S 2^{\circ}$ e os seguintes percentuais: I - mínimo de dez e máximo de vinte por cento sobre o valor da condenação ou do proveito econômico obtido até 200 (duzentos) salários-mínimos; II - mínimo de oito e máximo de dez por cento sobre o valor da condenação ou do proveito econômico obtido acima de 200 (duzentos) salários-mínimos até 2.000 (dois mil) salários-mínimos; III - mínimo de cinco e máximo de oito por cento sobre o valor da condenação ou do proveito econômico obtido acima de 2.000 (dois mil) salários-mínimos até 20.000 (vinte mil) salários-mínimos; IV - mínimo de três e máximo de cinco por cento sobre o valor da condenação ou do proveito econômico obtido acima de 20.000 (vinte mil) salários-mínimos até 100.000 (cem mil) salários-mínimos; V - mínimo de um e máximo de três por cento sobre o valor da condenação ou do proveito econômico obtido acima de 100.000 (cem mil) salários-mínimos. (grifo nosso)

104 Art. 77. CPC/15 - Além de outros previstos neste Código, são deveres das partes, de seus procuradores e de todos aqueles que de qualquer forma participem do processo: I - expor os fatos em juízo conforme a verdade; II - não formular pretensão ou de apresentar defesa quando cientes de que são destituídas de fundamento; III - não produzir provas e não praticar atos inúteis ou desnecessários à declaração ou à defesa do direito; IV - cumprir com exatidão as decisões jurisdicionais, de natureza provisória ou final, e não criar embaraços à sua efetivação; $\mathrm{V}$ - declinar, no primeiro momento que lhes 
seu exercício de forma dolosa e ilegal, penalizando o recorrente que tenha em qualquer momento do processo se utilizado de manobras procrastinatórias e que criam embaraço ao desfecho da demanda, nos termos da redação do parágrafo 12 do art. $85^{105}$, ora in comento. $\mathrm{Na}$ mesma toada, o entendimento de Guilherme Rizzo do Amaral:

Alguém poderá argumentar ser injusto onerar o recorrente por estar somente exercendo o seu direito ao recurso. Não se pode perder de vista, contudo, que quando se ajuíza uma ação em primeiro grau de jurisdição já se está exercendo o direito de ação, o qual o direito de recorrer é mera extensão. Logo, assim como não se argumenta que a fixação de honorários em primeiro grau de jurisdição sanciona o direito de ação, não se pode argumentar que a fixação de honorários cumulativos para a fase recursal assuma tal natureza. A medida visa à remuneração adequada do trabalho do advogado que, indubitavelmente, sofre importante acréscimo em termos de tempo e responsabilidade profissional por conta de sua atuação na esfera recursal. E veja-se que, ao fixar a verba honorária na sentença em primeiro grau de jurisdição, o juiz não possui ideia alguma acerca da extensão do trabalho adicional que terá o advogado na esfera recursal, o que constitui mais uma razão para que a verba honorária seja readequada nesta sede. ${ }^{106}$ (grifo nosso)

couber falar nos autos, o endereço residencial ou profissional onde receberão intimações, atualizando essa informação sempre que ocorrer qualquer modificação temporária ou definitiva; VI - não praticar inovação ilegal no estado de fato de bem ou direito litigioso. $\$ 1^{\circ}$ Nas hipóteses dos incisos IV e VI, o juiz advertirá qualquer das pessoas mencionadas no caput de que sua conduta poderá ser punida como ato atentatório à dignidade da justiça. $\S 2^{\circ} \mathrm{A}$ violação ao disposto nos incisos IV e VI constitui ato atentatório à dignidade da justiça, devendo o juiz, sem prejuízo das sanções criminais, civis e processuais cabíveis, aplicar ao responsável multa de até vinte por cento do valor da causa, de acordo com a gravidade da conduta. $§ 3^{\circ}$ Não sendo paga no prazo a ser fixado pelo juiz, a multa prevista no $\S 2^{-}$será inscrita como dívida ativa da União ou do Estado após o trânsito em julgado da decisão que a fixou, e sua execução observará o procedimento da execução fiscal, revertendo-se aos fundos previstos no art. 97. § 40 A multa estabelecida no § $2^{\circ}$ poderá ser fixada independentemente da incidência das previstas nos arts. 523, $\S 1^{\circ}$, e $536, \S 1^{\circ}$. $\S 5^{\circ}$ Quando o valor da causa for irrisório ou inestimável, a multa prevista no $§ 2^{\circ}$ poderá ser fixada em até 10 (dez) vezes o valor do salário-mínimo. § 6o Aos advogados públicos ou privados e aos membros da Defensoria Pública e do Ministério Público não se aplica o disposto nos $\S \S 2^{\circ}$ a $5^{\circ}$, devendo eventual responsabilidade disciplinar ser apurada pelo respectivo órgão de classe ou corregedoria, ao qual o juiz oficiará. § 7ํㅜ Reconhecida violação ao disposto no inciso VI, o juiz determinará o restabelecimento do estado anterior, podendo, ainda, proibir a parte de falar nos autos até a purgação do atentado, sem prejuízo da aplicação do $\S 2^{\circ}$. $\S 8^{\circ} \mathrm{O}$ representante judicial da parte não pode ser compelido a cumprir decisão em seu lugar. (grifo nosso)

${ }^{105}$ Os honorários referidos no $\$ 11$ são cumuláveis com multas e outras sanções processuais, inclusive as previstas no art. 77.

${ }^{106}$ AMARAL, Guilherme Rizzo. Comentários às alterações do novo CPC. São Paulo: Ed. RT, 2015. p. 155 . 


\section{PRINCÍPIO DA PRIMAZIA OU DA PREPONDERÂNCIA DO JULGAMENTO DO MÉRITO RECURSAL OU DA MITIGAÇÃO DA JURISPRUDÊNCIA DEFENSIVA}

A nosso ver, um dos pontos mais positivos e impactantes do Novo CPC na vida dos jurisdicionados é a prevalência do julgamento do mérito dos recursos em relação ao apego demasiado às formas, e como consequência, a não admissão dos recursos por cumprimento exacerbado das questões puramente técnicas, numa cultura nefasta arraigada nos tribunais de, na tentativa de diminuição do número de recursos, exagerar na cobrança dos requisitos de admissibilidade, inclusive com a utilização de entendimentos sem respaldo nenhum na Constituição ou nas leis para obstar o conhecimento de grande parte deles.

A essa cultura lesiva a direitos fomentada pelos tribunais de colocar a forma acima do conteúdo, de prejudicar o direito em razão do tecnicismo meramente formal na análise do recebimento dos recursos dáse o nome de jurisprudência defensiva, um verdadeiro desserviço que vinha sendo perpetrado pelos tribunais brasileiros há décadas.

Para Pedro Miranda de Oliveira, o termo correto não seria "jurisprudência defensiva", mas "jurisprudência ofensiva", pois ofende os princípios da legalidade, da inafastabilidade do controle jurisdicional, do contraditório, da boa-fé, da cooperação. Enfim, ofende o bom senso, a segurança jurídica e o princípio da razoabilidade. É ofensiva ao exercício da advocacia, pois coloca em xeque a relação cliente/advogado. E, dessa forma, ofende a cidadania. ${ }^{107}$

A título de exemplo dessas decisões formalistas era a súmula 115 do STJ que estabelecia que "Na instância especial é inexistente recurso interposto por advogado sem procuração nos autos", ao arrepio do que dispunha o art. 13 do $\mathrm{CPC} / 73^{108}$, que determinava que, ao verificar a irregularidade na representação, o juiz tinha que determinar a suspensão do processo e marcar um prazo razoável para que o defeito fosse sanado. $\mathrm{O}$

\footnotetext{
107 OLIVEIRA, Pedro Miranda de. in ALVIM, Teresa Arruda et al, coordenadores. Breves comentários ao Novo Código de Processo Civil. São Paulo: Ed. RT, 2015. p. 2.298.

${ }^{108}$ Art. 76. CPC/15 - Verificada a incapacidade processual ou a irregularidade da representação da parte, o juiz suspenderá o processo e designará prazo razoável para que seja sanado o vício. $§ 1$ 은 Descumprida a determinação, caso o processo esteja na instância originária: I - o processo será extinto, se a providência couber ao autor; II - o réu será considerado revel, se a providência lhe couber; III - o terceiro será considerado revel ou excluído do processo, dependendo do polo em que se encontre.
} 
artigo não limitava seu campo de aplicação, quanto a grau de jurisdição, questão atualmente superada pelo art. $76, \S 2^{\text {o109 }}$.

Outras manifestações demonstram esse comportamento censurável dos tribunais, tais como, a exigência de que o número do processo de origem constasse no recolhimento das guias judiciárias recursais, a impossibilidade de comprovação de referido local após a interposição do recurso para os tribunais superiores (essa questão veio sendo mitigada), a declaração de intempestividade do recurso interposto antes da publicação da decisão no diário oficial, que marca o início de seu prazo ("recurso prematuro", matéria que será estudada adiante) e o não conhecimento de recurso especial não ratificado após o julgamento de embargos de declaração da parte contrária.

Talvez o mais corriqueiro e absurdo exemplo dessa práxis era a não admissão do recurso do agravo de instrumento por faltarem cópias, que embora não fossem obrigatórias (art. 525, II do CPC/73 ${ }^{110}$ ), impediam a exata compreensão da controvérsia, o que deixava ao talante do órgão julgador inadmitir o recurso mesmo que as cópias obrigatórias estivessem presentes, sem dar prazo para regularização. Casos ocorreram que, o agravante, no afã do cumprimento do prazo acabou por tirar uma cópia

109 Art. 76. CPC/15 - Verificada a incapacidade processual ou a irregularidade da representação da parte, o juiz suspenderá o processo e designará prazo razoável para que seja sanado o vício. $§ 10$ Descumprida a determinação, caso o processo esteja na instância originária: I - o processo será extinto, se a providência couber ao autor; II - o réu será considerado revel, se a providência lhe couber; III - o terceiro será considerado revel ou excluído do processo, dependendo do polo em que se encontre. \$20 Descumprida a determinação em fase recursal perante tribunal de justiça, tribunal regional federal ou tribunal superior, o relator: I - não conhecerá do recurso, se a providência couber ao recorrente; II determinará o desentranhamento das contrarrazões, se a providência couber ao recorrido. (grifo nosso) ${ }^{110}$ Art. 1.017. CPC/15 - A petição de agravo de instrumento será instruída: I - obrigatoriamente, com cópias da petição inicial, da contestação, da petição que ensejou a decisão agravada, da própria decisão agravada, da certidão da respectiva intimação ou outro documento oficial que comprove a tempestividade e das procurações outorgadas aos advogados do agravante e do agravado; II - com declaração de inexistência de qualquer dos documentos referidos no inciso I, feita pelo advogado do agravante, sob pena de sua responsabilidade pessoal;

III - facultativamente, com outras peças que o agravante reputar úteis. § 1으스. Acompanhará a petição o comprovante do pagamento das respectivas custas e do porte de retorno, quando devidos, conforme tabela publicada pelos tribunais. $\S 2^{\underline{o}}$ No prazo do recurso, o agravo será interposto por: I - protocolo realizado diretamente no tribunal competente para julgá-lo; II - protocolo realizado na própria comarca, seção ou subseção judiciárias; III - postagem, sob registro, com aviso de recebimento; IV - transmissão de dados tipo fac-símile, nos termos da lei; V - outra forma prevista em lei. § $3^{\circ} \mathrm{Na}$ falta da cópia de qualquer peça ou no caso de algum outro vício que comprometa a admissibilidade do agravo de instrumento, deve o relator aplicar o disposto no art. 932, parágrafo único. $\S 4^{\circ}$ Se o recurso for interposto por sistema de transmissão de dados tipo fac-símile ou similar, as peças devem ser juntadas no momento de protocolo da petição original. § 5을 Sendo eletrônicos os autos do processo, dispensamse as peças referidas nos incisos I e II do caput, facultando-se ao agravante anexar outros documentos que entender úteis para a compreensão da controvérsia. 
ilegível ou com a folha dobrada e tinha o recurso não conhecido. Aqui se fala de processos que refletiam o patrimônio do litigante, sua estabilidade, suas expectativas, seu futuro, sua família, enfim, tudo era posto de lado por conta de rigorismos formais que nada têm a ver com a verdadeira aplicação da justiça, ao contrário, evidenciavam uma negativa absoluta de prestação jurisdicional. Destaca-se ainda que se os autos forem eletrônicos, haverá a dispensa destas cópias, cuja exigência tem sentido apenas nos processos físicos ainda existentes no país.

Não se defende aqui a informalidade prejudicial ao bom andamento do processo, até porque a atividade admissional é imprescindível para o desenvolvimento válido e regular do processo. Assim, se faltar fundamentação ao recurso ou o recorrente deixar de impugnar especificamente cada motivo elencado na decisão não há como se proceder a regularização, pela vedação da complementaridade ou em atendimento ao princípio da preclusão consumativa. Numa amostra mais significativa, o recurso intempestivo não pode e nem deve ser aceito, pois isso feriria de morte o sistema dos prazos preclusivos e peremptórios do processo. Fala-se apenas de atos e situações que seu saneamento não prejudica em nada a busca da aplicação do direito material ao caso subjacente, com vistas à efetiva atuação do Poder Judiciário na busca de uma decisão de mérito.

Nota-se na exposição de motivos do Novo CPC que há um esforço do novo diploma em entregar à sociedade a efetiva realização dos direitos ameaçados de lesão ou violados, em prol das garantias constitucionais de um Estado Democrático de Direito, que não pode privilegiar a forma em detrimento do conteúdo sob pena de se afastar do devido processo legal, da coesão, e, em última análise, do acesso à justiça (artigos $3^{\circ}$ do NCPC ${ }^{111}$ e $5^{\circ}, \mathrm{XXXV}^{112}$ da Constituição Federal), regras e princípios que devem permear todo um sistema jurídico.

Na prática, o Novo CPC evidencia sua pretensão de favorecer a aplicação do direito material em detrimento do vício formal através de vários artigos, conforme alguns destacados:

\footnotetext{
111 Art. 3o CPC/15 - Não se excluirá da apreciação jurisdicional ameaça ou lesão a direito. § 1ำ É permitida a arbitragem, na forma da lei. § $2^{\circ}$ O Estado promoverá, sempre que possível, a solução consensual dos conflitos. $\S 3^{\circ}$ A conciliação, a mediação e outros métodos de solução consensual de conflitos deverão ser estimulados por juízes, advogados, defensores públicos e membros do Ministério Público, inclusive no curso do processo judicial.

${ }^{112}$ Art. $5^{\circ}, \mathrm{XXXV/CF}$ - a lei não excluirá da apreciação do Poder Judiciário lesão ou ameaça a direito;
} 
I) Art. 76, $§ \mathbf{2}^{\mathbf{0 1 1 3}}$ - deixa claro que o regramento do revogado art. 13 do CPC/73 se aplica à instância recursal, de modo que, em caso de incapacidade processual ou irregularidade de representação da parte, como a falta de procuração outorgada ao advogado, deverá o relator possibilitar a correção do vício em prazo razoável, antes que não conheça do recurso ou determine o desentranhamento das contrarrazões ${ }^{114115}$;

II) Art. 218, $\$ \mathbf{4}^{\mathbf{0 1 1 6}}$ - estabelece a tempestividade do ato praticado (interposição de recurso, por exemplo) antes do termo inicial do prazo, afastando jurisprudência aplicada durante muito tempo pelos tribunais superiores e confirmada pelo proparoxítono entendimento estampado na Súmula 418 do STJ que dispunha: É inadmissível o recurso especial interposto antes da publicação do acórdão dos embargos de declaração, sem posterior ratificação. (grifo nosso)

III) Art. 932, parágrafo único ${ }^{117}$ - Este dispositivo se constitui num dos mais importantes meios de combate à jurisprudência defensiva, pois obriga o julgador a facultar ao recorrente o prazo de 5 dias para sanar algum defeito do recurso antes de inadmiti-lo, diferentemente do que dispunha o $\S 4^{\circ}$ do art. 514 do CPC revogado que tratava da apelação e

113 Art. 76 CPC/15 - Verificada a incapacidade processual ou a irregularidade da representação da parte, o juiz suspenderá o processo e designará prazo razoável para que seja sanado o vício. $§ 10$ Descumprida a determinação, caso o processo esteja na instância originária: I - o processo será extinto, se a providência couber ao autor; II - o réu será considerado revel, se a providência lhe couber; III - 0 terceiro será considerado revel ou excluído do processo, dependendo do polo em que se encontre. $\S 2^{\circ}$ Descumprida a determinação em fase recursal perante tribunal de justiça, tribunal regional federal ou tribunal superior, o relator: I - não conhecerá do recurso, se a providência couber ao recorrente; II determinará o desentranhamento das contrarrazões, se a providência couber ao recorrido. (grifo nosso) ${ }^{114}$ Cf. OLIVEIRA JR., Zulmar Duarte de; ROQUE, André Vasconcelos; GAJARDONI, Fernando da Fonseca; DELLORE, Luiz. A jurisprudência defensiva ainda pulsa no novo CPC. Disponível < http://www.conjur.com.br/2013-set-06/jurisprudencia-defensiva-ainda-pulsa-codigo-processo-civil > Acesso em 15.06.2016.

115 Neste sentido é o Enunciado n. 83 do Fórum Permanente de Processualistas Civis: "(art. 932 parágrafo único; art. $76, \S 2^{\circ}$.; art. $104, \S 2^{\circ}$.; art. $1.029, \S 3^{\circ}$.) Fica superado o enunciado 115 da súmula do STJ após a entrada em vigor do CPC ("Na instância especial é inexistente recurso interposto por advogado sem procuração nos autos"). (Grupo: Ordem dos Processos no Tribunal, Teoria Geral dos Recursos, Apelação e Agravo)".

${ }^{116}$ Art. 218. CPC/15 - Os atos processuais serão realizados nos prazos prescritos em lei.§ 1o Quando a lei for omissa, o juiz determinará os prazos em consideração à complexidade do ato. § 2o Quando a lei ou o juiz não determinar prazo, as intimações somente obrigarão a comparecimento após decorridas 48 (quarenta e oito) horas. § 3o Inexistindo preceito legal ou prazo determinado pelo juiz, será de 5 (cinco) dias o prazo para a prática de ato processual a cargo da parte. § 4 o Será considerado tempestivo $\mathrm{o}$ ato praticado antes do termo inicial do prazo. (grifo nosso)

${ }^{117}$ Art. 932. CPC/15 - Parágrafo único. Antes de considerar inadmissível o recurso, o relator concederá o prazo de 5 (cinco) dias ao recorrente para que seja sanado vício ou complementada a documentação exigível. 
continha a expressão "poderá", transferindo ao tribunal a faculdade de mandar proceder com a correção do vício ou não.

IV) Art. 938, $\S \mathbf{1}^{\mathbf{1 1 1 8}}$ - No mesmo sentido e até mesmo de forma redundante o legislador deixa claro que a política processual é de acertamento dos vícios sanáveis para o regular prosseguimento do julgamento do recurso. Alguns vícios são sanáveis no próprio tribunal, como a não apresentação de contrarrazões ou falta de assinatura do advogado no recurso ou de um perito em seu laudo, alguns outros vícios necessitam que o processo seja devolvido ao grau de origem para a sua sanação, convertendo-se o julgamento em diligência, com a devida intimação das partes de todas essas ocorrências. ${ }^{119}$

V) Art. 1.003, $\$ \mathbf{4}^{\mathbf{0 1 2 0}}$ - Superando a súmula 216 STJ, que indicava que a tempestividade de recurso interposto no Superior Tribunal de Justiça é aferida pelo registro no protocolo da Secretaria e não pela data da entrega na agência do correio, esse parágrafo quarto impõe nova regra que determina que para aferição da tempestividade do recurso remetido pelo correio, será considerada como data de interposição a data de postagem, se coadunando com a forma mais justa e rente à realidade da vida prática do advogado que não ficará à mercê da efetiva entrega do recurso no prazo no tribunal, ou seja, a data da postagem é o marco caracterizador do cumprimento do prazo. ${ }^{121}$

VI) Art. 1.007 - e seus parágrafos ${ }^{122}$ - Deserção é a penalidade processual da não admissão de um recurso pela falta de recolhimento das

\footnotetext{
${ }^{118}$ Art. $938, \S 1^{\circ}$. CPC/15 - Constatada a ocorrência de vício sanável, inclusive aquele que possa ser conhecido de ofício, o relator determinará a realização ou a renovação do ato processual, no próprio tribunal ou em primeiro grau de jurisdição, intimadas as partes.

${ }^{119}$ Neste sentido é o Enunciado n. 332 do Fórum Permanente de Processualistas Civis: “(art. 938, $\S 1^{\circ}$.; art. 15). Considera-se vício sanável, tipificado no art. $938, \S 1^{\circ}$., a apresentação da procuração e da guia de custas ou depósito recursal em cópia, cumprindo ao relator assinalar prazo para a parte renovar o ato processual com a juntada dos originais. (Grupo: Impacto do CPC no processo do trabalho)".

${ }^{120}$ Art. $1.003, \S 4^{\circ}$. CPC/15 - Para aferição da tempestividade do recurso remetido pelo correio, será considerada como data de interposição a data de postagem.

${ }^{121}$ Neste sentido é o Enunciado n. 96 do Fórum Permanente de Processualistas Civis: "(art. 1.003, §4.) Fica superado o enunciado 216 da súmula do STJ após a entrada em vigor do CPC ("A tempestividade de recurso interposto no Superior Tribunal de Justiça é aferida pelo registro no protocolo da Secretaria e não pela data da entrega na agência do correio"). (Grupo: Ordem dos Processos no Tribunal, Teoria Geral dos Recursos, Apelação e Agravo).

${ }^{122}$ Art. 1.007. CPC/15 - No ato de interposição do recurso, o recorrente comprovará, quando exigido pela legislação pertinente, o respectivo preparo, inclusive porte de remessa e de retorno, sob pena de deserção. § 10 São dispensados de preparo, inclusive porte de remessa e de retorno, os recursos interpostos pelo Ministério Público, pela União, pelo Distrito Federal, pelos Estados, pelos Municípios, e respectivas autarquias, e pelos que gozam de isenção legal. $\S 2^{\circ} \mathrm{A}$ insuficiência no valor do preparo, inclusive porte de remessa e de retorno, implicará deserção se o recorrente, intimado na pessoa de seu
} 
custas judiciárias (preparo). De acordo com esse artigo, a deserção será aplicada somente após escoar o prazo de 5 dias para que o recorrente tenha oportunidade de recolher as custas faltantes ou se nada recolheu, recolhêlas em dobro, conforme será estudado no capítulo sobre requisitos de admissibilidade recursais. ${ }^{123}$

Ainda neste artigo, uma solução simples e eficaz para outro problema que impedia o conhecimento do recurso sob a égide do CPC anterior, a que determina que o equívoco no preenchimento da guia de custas (como, por exemplo, a falta de referência ao número do processo na origem) não resultará na aplicação da pena de deserção, incumbindo ao relator, em caso de dúvida quanto ao recolhimento, intimar o recorrente para sanar o vício em cinco dias $\left(\S 7^{\circ}\right)$.

VII) Art. 1.017, $\S 3^{\text {0124 }}$ - Conforme comentários no início deste tópico, um dos atos que provocavam as mais ácidas críticas da doutrina e da classe dos advogados, era o entendimento cristalizado pela jurisprudência de que se faltassem cópias, mesmo classificadas como facultativas na formação do agravo de instrumento, o tribunal poderia não conhecer do recurso porque a ausência poderia obstruir a compreensão da exata dimensão da controvérsia. ${ }^{125}$

advogado, não vier a supri-lo no prazo de 5 (cinco) dias. § 3ํ É dispensado o recolhimento do porte de remessa e de retorno no processo em autos eletrônicos. $\S 4^{\circ} \mathrm{O}$ recorrente que não comprovar, no ato de interposição do recurso, o recolhimento do preparo, inclusive porte de remessa e de retorno, será intimado, na pessoa de seu advogado, para realizar o recolhimento em dobro, sob pena de deserção. § $5^{\circ}$ É vedada a complementação se houver insuficiência parcial do preparo, inclusive porte de remessa e de retorno, no recolhimento realizado na forma do $\S 4^{\circ}$. $§ 6^{\circ}$ Provando o recorrente justo impedimento, o relator relevará a pena de deserção, por decisão irrecorrível, fixando-lhe prazo de 5 (cinco) dias para efetuar o preparo. $\S 7^{\circ} \mathrm{O}$ equívoco no preenchimento da guia de custas não implicará a aplicação da pena de deserção, cabendo ao relator, na hipótese de dúvida quanto ao recolhimento, intimar o recorrente para sanar o vício no prazo de 5 (cinco) dias.

${ }^{123}$ Vale observar o Enunciado n. 215 do Fórum Permanente de Processualistas Civis: n "(art. 1.007, $\S \S 2^{\circ}$. e $4^{\circ}$.). Fica superado o enunciado 187 da súmula do STJ ("É deserto o recurso interposto para o Superior Tribunal de Justiça, quando o recorrente não recolhe, na origem, a importância das despesas de remessa e retorno dos autos"). (Grupo: Ordem dos Processos nos Tribunais e Recursos Ordinários)". ${ }^{124}$ Art. $1.017, \S 3^{\circ}$. CPC/15 - Na falta da cópia de qualquer peça ou no caso de algum outro vício que comprometa a admissibilidade do agravo de instrumento, deve o relator aplicar o disposto no art. 932, parágrafo único.

${ }^{125}$ Após longos anos, este entendimento já vinha sendo mitigado, conforme se percebe no julgamento do STJ no REsp n. 1.102.467-RJ, proferido de acordo com a sistemática dos recursos repetitivos, fixou a seguinte tese: "no agravo do artigo 522 do CPC, entendendo o Julgador ausente peças necessárias para a compreensão da controvérsia, deverá ser indicado quais são elas, para que o recorrente complemente o instrumento". No entanto, o dispositivo do NCPC em comento é mais amplo, abarcando não só as cópias de peças facultativas do processo original, como também "qualquer peça" e, ainda, "qualquer outro vício que comprometa a admissibilidade do agravo de instrumento". Avançou, pois, o NCPC no combate à jurisprudência defensiva dos Tribunais. 
Pondo fim a essa polêmica, a novel lei obriga o relator a aplicar o parágrafo único do art. 932, ou seja, a conceder o prazo de 5 dias para que a parte junte eventual cópia faltante. Vale recordar que a exigência de juntada de cópias vale apenas e tão somente para os processo físicos ainda em curso, dispensando-se as mesmas nos processos eletrônicos, haja vista que nestes últimos, o tribunal tem pleno acesso aos autos que tramitam em primeiro grau de jurisdição, conforme será abordado no capítulo sobre o "agravo de instrumento".

VIII - Art. 1.029, $§ 3^{\mathbf{0 1 2 6}}$ - Em perfeita consonância com as linhas mestras do Novo Código, este artigo impõe que o Supremo Tribunal Federal ou o Superior Tribunal de Justiça poderá desconsiderar vício formal de recurso tempestivo (consunção processual), ou determinar sua correção, desde que não o repute grave, re-ratificando que o combate às inócuas filigranas formais que dificultam o acesso à justiça também se aplicam aos tribunais superiores. Caberá na aplicação da referida regra, da conformação mais ou menos formalista da jurisprudência destes tribunais.

IX - Art. $\mathbf{1 0 2 5}^{127}$ - admite o prequestionamento implícito ou virtual, no sentido de se considerar incluídos no acórdão recorrido, os elementos que o embargante pleiteou, para fins de prequestionamento, ainda que os embargos de declaração sejam inadmitidos ou rejeitados, caso o tribunal superior considere existentes erro, omissão, contradição ou obscuridade $^{128}$. O prequestionamento será estudado em conjunto com os recursos especial e extraordinário adiante, como requisitos para admissão desses recursos pelos tribunais superiores.

X - Art. 1024, $§ \mathbf{5}^{\mathbf{0 1 2 9}}$ - neste caso, há a dispensa da necessidade de ratificação de recurso interposto anteriormente ao julgamento de embargos de declaração opostos pela parte contrária, desde que eles não alterem a conclusão do julgamento anterior (decisão embargada), restando

\footnotetext{
${ }^{126}$ Art. $1.029, \S 3^{\circ}$. CPC/15 - O Supremo Tribunal Federal ou o Superior Tribunal de Justiça poderá desconsiderar vício formal de recurso tempestivo ou determinar sua correção, desde que não o repute grave.

${ }^{127}$ Art. 1.025. CPC/15 - Consideram-se incluídos no acórdão os elementos que o embargante suscitou, para fins de pré-questionamento, ainda que os embargos de declaração sejam inadmitidos ou rejeitados, caso o tribunal superior considere existentes erro, omissão, contradição ou obscuridade.

${ }^{128}$ Cf. OLIVEIRA JR., Zulmar Duarte de; ROQUE, André Vasconcelos; GAJARDONI, Fernando da Fonseca; DELLORE, Luiz. A jurisprudência defensiva ainda pulsa no novo CPC. Disponível < http://www.conjur.com.br/2013-set-06/jurisprudencia-defensiva-ainda-pulsa-codigo-processo-civil > Acesso em 15.06.2016.

${ }^{129}$ Art. $1.024, \S 5^{\circ}$. CPC/15 - Se os embargos de declaração forem rejeitados ou não alterarem a conclusão do julgamento anterior, o recurso interposto pela outra parte antes da publicação do julgamento dos embargos de declaração será processado e julgado independentemente de ratificação.
} 
superado o entendimento firmado na Súmula 418 do STJ que dispunha: $E$ inadmissível o recurso especial interposto antes da publicação do acórdão dos embargos de declaração, sem posterior ratificação.

XI - Art. $\mathbf{1 0 3 2}^{\mathbf{1 3 0}}$ - permite o aproveitamento do recurso especial e sua conversão em extraordinário, caso se considere que a insurgência versa sobre questão constitucional.

XII - Art. $1033^{131}$ - permite o aproveitamento do recurso extraordinário e sua conversão em especial para o Superior Tribunal de Justiça, caso o Supremo Tribunal Federal considere como reflexa a ofensa à Constituição nele veiculada, por pressupor a revisão da interpretação de lei federal ou de tratado ${ }^{132}$. Esses dois últimos artigos preveem a aplicação da fungibilidade entre e os recursos extraordinário e especial, um expressivo avanço na admissão desses dois recursos, matérias que serão tratadas adiante no capítulo recursos para os tribunais superiores. Oliveira $^{133}$ :

Como enlace, vale a lição de Carlos Alberto Álvaro de (...) as formas processuais cogentes não devem ser consideradas "formas eficácias" (Wirkform), mas "formas finalísticas" (Zweckform), subordinadas de modo instrumental às finalidades processuais, a impedir assim o entorpecimento do rigor formal processual, materialmente determinado, por um formalismo de forma sem conteúdo. A esse ângulo visual, as prescrições formais devem ser sempre apreciadas conforme sua finalidade e sentido razoável, evitando-se todo exagero das exigências de forma. Se a finalidade da prescrição foi atingida na sua essência, sem prejuízo a interesses dignos de proteção da contraparte, o defeito de forma não deve prejudicar a parte. A forma não pode, assim, ser colocada "além da matéria", por não possuir valor próprio, devendo por razões de equidade a essência sobrepujar a forma.

${ }^{130}$ Art. 1.032. CPC/15 - Se o relator, no Superior Tribunal de Justiça, entender que o recurso especial versa sobre questão constitucional, deverá conceder prazo de 15 (quinze) dias para que o recorrente demonstre a existência de repercussão geral e se manifeste sobre a questão constitucional.

131 Art. 1.033. CPC/15 - Se o Supremo Tribunal Federal considerar como reflexa a ofensa à Constituição afirmada no recurso extraordinário, por pressupor a revisão da interpretação de lei federal ou de tratado, remetê-lo-á ao Superior Tribunal de Justiça para julgamento como recurso especial.

${ }^{132}$ Cf. OLIVEIRA JR., Zulmar Duarte de; ROQUE, André Vasconcelos; GAJARDONI, Fernando da Fonseca; DELLORE, Luiz. A jurisprudência defensiva ainda pulsa no novo CPC. Disponível < http://www.conjur.com.br/2013-set-06/jurisprudencia-defensiva-ainda-pulsa-codigo-processo-civil > Acesso em 15.06.2016.

133 OLIVEIRA, Carlos Alberto Álvaro de. O Formalismo-valorativo no confronto com o Formalismo excessivo. Revista de Processo, ano 31, nº 137. São Paulo: Ed. RT, julho de 2006, p. 5. 
Este é o novo padrão, em se tratando de vício sanável, deverá ser oportunizado prazo para a parte poder renovar o ato, de forma a possibilitar o exame do conteúdo do processo, da matéria de fundo, para uma decisão justa e efetiva ser proferida.

\section{CONCLUSÃO}

O novo CPC transpareceu de forma inconteste a tentativa de que as decisões judiciais possam atingir o mérito da causa, formando um novo arquétipo no qual o jurisdicionado tenha o direito não somente à ação, mas como resultado dessa ação a análise do direito material, evitando que a solução definitiva seja postergada para outro processo.

Com isso, percebe-se claramente que há preponderência do conteúdo em relação à forma, o que, num Estado Democrático de Direito que alberga o acesso à justiça no topo de seus valores, esse acesso alcança um novo patamar, no qual o "resultado justo" deve ser buscado com total prevalência ante aos rigorismos formais criados pela jurisprudência a partir do revogado Código de Buzaid.

Como produto dessa alteração principiológica, resta-nos a esperança de que a tão prejudicial jurisprudência defensiva, criada pelos tribunais a partir do prestígio ao excesso de formalismo processual, seja de vez sepultada, em nome do bom senso, da efetividade da prestação jurisdicional e do respeito máximo a todos os cidadãos sujeitos ao poder substitutivo estatal de dar solução aos conflitos de forma definitiva, satisfatória e pacificadora.

\section{REFERÊNCIAS BIBLIOGRÁFICAS}

ALVIM, Teresa Arruda et al, coordenadores. Breves comentários ao Novo Código de Processo Civil. São Paulo: Ed. RT, 2015.

AMARAL, Guilherme Rizzo. Comentários às alterações do novo CPC. São Paulo: Ed. RT, 2015.

BIM, Eduardo Fortunato; MAIDAME, Márcio Manoel. Restrições ao poder geral de cautela e derrotabilidade. São Paulo: Ed. RT, ago. 2009.

BRASIL. 523/STJ: $4^{\text {a }}$ Turma, AgRg no AREsp 9.653/SP, rel. Min. Luis Felipe Salomão, j. 02/05/2013. 
STF, $1^{a}$ T., RE 88.372/BA, Rel.Min. Bilac Pinto, ac. 24.11.1997, RTJ 85/722; STJ, $4^{\text {a }}$ T., RMS 751/GO, Rel.Min. Sálvio de Figueiredo, ac. 09.04.1991, DJU 13.05.1991, P. 6.048; STJ, $3^{\text {a }}$ T., AgRg no REsp 1.241.594/RS, Rel.Min. Sidnei Beneti, ac. 21.06.2011, DJe 27.06.2011.

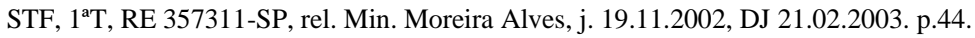

STJ, $2^{\mathrm{a}}$ T, AgRg no AREsp 571.026/PE, rel. Min. Mauro Campbell Marques, j. 21/10/2014, DJe $28 / 10 / 2014$. 16.09.2009.

STJ, $2^{\text {a }}$ T., AgRg no REsp 1.012.086/RJ, rel. Min. Humberto Martins, j. 25.08.2009, DJe

. STJ, $2^{\text {a }}$ Turma REsp 981.591/RS, rel. Min. Humberto Martins, j. 25.03.2008, DJe 03/04/2008.

STJ, $4^{a}$ T., REsp 113.443/PR rel. Min. (p/o Ac.) Min. Sálvio de Figueiredo Teixeira, j. 11.12.2001, DJ 01.07.2004, p. 195).

STJ, $4^{\circ}$ T, EDclREsp 1338937-PR, rel. Min. Luis Felipe Salomão, j. 3.4.2014, DJUE 11.04.2014 / EDcl no AREsp 399.852/RJ, Rel. Min. Eliana Calmon, 2ª T., j. 17.12.2013, DJe 07.02.2104.

STJ, Corte especial, AgRg no RO nos EDcL no AgRg no MS 10.652/DR,Rel.Min. Ari Pargendler, ac. 12.04.2010, DJe 02.05.2010. Na mesma linha decidiram: STJ, ${ }^{\text {a }}$ T.,(EDcL no REsp 1.106.143/MG, DJe 26.03.2010); $2^{\mathrm{a}} \mathrm{T}$.,(AgRg no REsp 599.458/RS, DJe 11.11.2009), ${ }^{\mathrm{a}} \mathrm{T}$.(AgRg no REsp 1.067.946/RN, Dje 07.12.2010) e $4^{\mathrm{a}}$ T.(REsp 1.035.169/BA, DJe 08.02.2010).

BUENO, Cassio Scarpinella. Curso sistematizado de direito processual civil.: recursos, processos e incidentes nos tribunais, sucedâneos recursais: técnicas de controle das decisões jurisdicionais. São Paulo: Saraiva, 2008. v. 5.

CRETELLA NETO, José. Fundamentos principiológicos do processo civil. Rio de Janeiro: Forense, 2002.

DIDIER JUNIOR, Fredie; CUNHA, Leonardo José Carneiro da, Curso de direito processual civil: meios de impugnação às decisões judiciais. $5^{\mathrm{a}}$.ed. Salvador: JusPodivm, 2008.

DONIZETTI, Elpídio. Curso didático de direito processual civil. 19 ed. rev. e completamente reformulada conforme o Novo CPC - Lei 13.105, 16 de março de 2015 e atualizada com a Lei 13.256, de 04 de fevereiro de 2016. - São Paulo: Atlas, 2016.

FUX, Luiz. Curso de direito processual civil. Rio de Janeiro: Forense, 2001.

GAJARDONI, Fernando da Fonseca. Reflexos do tempo no direito processual civil - anotações sobre a qualidade temporal do processo civil brasileiro e europeu. São Paulo: Ed. RT, nov. 2007.

GONÇALVES, Marcus Vinicius Rios. Novo curso de direito processual civil, volume 2: processos de conhecimento ( $2^{\mathrm{a}}$ parte) e procedimentos especiais. 3. ed. rev. e atual. São Paulo: Saraiva, 2007. 
JORGE, Flávio Cheim. Teoria geral dos recursos cíveis. 7. ed. rev., atual. e ampl. - São Paulo: Ed. RT, 2015.

LASPRO, Orestes Nestor de Souza. Duplo grau de jurisdição no direito processual civil. São Paulo: Ed. RT, 1995.

MARINONI, Luiz Guilherme; ARENHART, Sérgio Cruz. Manual do processo de conhecimento. 5.ed. São Paulo: Revista dos Tribunais, 2006.

MEDINA, José Miguel Garcia; WAMBIER, Teresa Arruda Alvim. Recursos e ações autônomas de impugnação. São Paulo: Editora Revista dos Tribunais, 2008.

MENDONÇA JUNIOR., Delosmar. A decisão monocrática do relator e o agravo interno na teoria geral dos recursos. Tese de doutoramento. Pontifícia Universidade Católica de São Paulo, 2006 DIDIER JR., Fredie; CUNHA, Leonardo José Carneiro da, Curso de direito processual civil: meios de impugnação às decisões judiciais. $5^{\text {a }}$.ed. Salvador: JusPodivm, 2008.

MIRANDA, Gilson Delgado; PIZZOL, Patricia Miranda. Recursos no processo civil. 6. ed. atual. São Paulo: Atlas, 2009.

MOREIRA, Barbosa apud JORGE, Flávio Cheim. Teoria geral dos recursos cíveis. 7. ed. rev., atual. e ampl. - São Paulo: Ed. RT, 2015. p. 309.

NERY JUNIOR, Nelson. Teoria geral dos recursos. 5. ed. São Paulo: Ed RT.

NEVES, Daniel Amorim Assumpção. Manual de direito processual civil - volume único.8. ed Salvador: Ed. JusPodivim, 2016.

OLIVEIRA JUNIOR., Zulmar Duarte de; ROQUE, André Vasconcelos; GAJARDONI, Fernando da Fonseca; DELLORE, Luiz. A jurisprudência defensiva ainda pulsa no novo CPC. Disponível < http://www.conjur.com.br/2013-set-06/jurisprudencia-defensiva-ainda-pulsa-codigo-processo-civil > Acesso em 15.06.2016.

OLIVEIRA, Bruno Silveira de. Duplo grau de jurisdição: princípio constitucional?. São Paulo: Ed. RT, ago. 2008. p.

OLIVEIRA, Pedro Miranda de. in ALVIM, Teresa Arruda et al, coordenadores. Breves comentários ao Novo Código de Processo Civil. São Paulo: Ed. RT, 2015.

ORIONE NETO, Luiz. Recursos cíveis. 2. ed. São Paulo: Saraiva, 2006.

PANTOJA, Fernanda Medina in ALVIM, Teresa Arruda et al, coordenadores. Breves comentários ao Novo Código de Processo Civil. São Paulo: Ed. RT, 2015.

SUNDFELD, Carlos Ari. Fundamentos de Direito Público. 4.ed. rev., aumentada e atualizada. São Paulo: Malheiros, 2005.

TEIXEIRA, Guilherme Puchalski. Análise fragmentada do duplo grau, enquanto regra de direito. São Paulo: Ed. RT, abr. 2008. 
THEODORO Júnior, Humberto. Curso de Direito Processual Civil - Teoria geral do direito processual civil, processo de conhecimento e procedimento comum - vol. III. 46. ed. - Rio de Janeiro: Forense, 2016. p. 953.

Curso de direito processual civil. v.1. Rio de Janeiro: Forense, 2009.

VEIGA, Pimenta in THEODORO Júnior, Humberto. Curso de Direito Processual Civil - Teoria geral do direito processual civil, processo de conhecimento e procedimento comum - vol. III. 46. ed. - Rio de Janeiro: Forense, 2016. 